\title{
A Critical Edition and Philological Analysis of the Text of Isa 46-48 on the Basis of the Coptic Manuscript sa 52 (M 568) and other Coptic Manuscripts in the Sahidic Dialect and the Greek Text of the Septuagint
}

\author{
TOMASZ BARTKOMIEJ BĄK \\ The John Paul II Catholic University of Lublin \\ tomasz.bak@kul.pl \\ ORCID: 0000-0003-0328-0282
}

\begin{abstract}
The article constitutes a critical edition and a philological analysis of the text of Isa 46-48, based on the Coptic manuscript sa 52 and other available manuscripts in the Sahidic dialect. The first part provides general information on this fragment of the codex sa 52 (M 568), which includes the text being elaborated. This is followed by a list and a brief description of the remaining manuscripts, containing at least some verses from Isa 46-48. The most significant part of the article is the presentation of the Coptic text (in the Sahidic dialect) as well as its translation into English. The differences noted between the Sahidic text and the Greek Septuagint, on which the Coptic translation is based, are presented in a tabular form. It includes, i.a., additions and omissions in the Coptic translation, lexical changes and semantic differences. The last part of the article is devoted to more difficult philological issues, observed either in the Coptic text itself or in its relation to the Greek text LXX. Particularly noteworthy are those verses of Isa 46-48, which appear only in the manuscript sa 52 and have not been published anywhere so far.
\end{abstract}

Keywords: Coptic language, Sahidic dialect, Book of Isaiah, Deutero-Isaiah, sa 52 (M 568), CLM 205, edition of Isa 46-48

A fter the announcement of universal conversion and the homage that the Gentiles will pay to God the Creator (Isa 45:14-25), the author of the Book of Isaiah points to the contrast between pagan idols and the God of Jacob (Isa 46). Babylonian deities such as Bel and Nebo are merely dead statues made of precious gold and silver (Isa 46:1-7). The God that the prophet Isaiah proclaims is a God who does wonders. He revealed His omnipotence in the past, and now $\mathrm{He}$ will show it again through Cyrus, who will contribute to freeing the Jewish people from Babylonian captivity (Isa 46:8-13).

After showing the contrast between the True God and pagan idols, the Book of Isaiah contains the text, which is commonly referred to as "the Satire of Babylon" (Isa 47). The Prophet sees Babylon humiliated. The proud ruler of half of the world will become a slave sitting on the ground (vv. 1-4). Her pride went 
beyond the measure in humiliating the captivated nation of Israel (vv. 5-7). She will suffer severe punishment for her sin, becoming like a woman who has lost her husband and children (vv. 8-9). No magic spells or the meticulous knowledge of Babylonian astrologers will help her (vv. 10-15). Babylon has already been doomed and can be summed up in the last words: "there is not one that can save you" (47:15c).

The proof of the truthfulness of the God of Israel is in His fulfilled prophecies (48:1-11). Based on what God has accomplished, the nation should believe in the promises concerning the future. In particular, one of them is the announcement of the liberation of Israel from Babylonian captivity by the Persian king Cyrus (48:12-16). However, prosperity and God's help depend on obedience to His commandments (48:17-19). The last three verses of chapter 48 summarise what the prophet spoke about earlier: the fall of Babylon is bound to come, and the nation of Israel is called to escape captivity.

The subject of this article will be the edition of the Coptic chapters of Isa 46-48, which is a continuation of the text from the Book of Isaiah which has been elaborated so far. ${ }^{1}$ It will be based mainly on the Sahidic manuscript sa 52 (M 568), ${ }^{2}$ listed in the currently created electronic database under the name: CLM 205. ${ }^{3}$ This paper is based on both the photographic edition (the so-called facsimile), provided by the Vatican Library, and the microfilm, provided by the Morgan Library in New York. For several years now, black and white photos of the Library's Coptic collection have been made available on the website: https://archive.org/ details/PhantoouLibrary. ${ }^{4}$ The coloured edition of the facsimile has also become available recently as part of the Digital Edition of the Coptic Old Testament project on the website: http://coptot.manuscriptroom.com/manuscript-workspace. ${ }^{5}$ In this study, our manuscript received another designation: sa 2008, ${ }^{6}$ which of

1 An edition of the Proto-Isaiah text, based on the manuscript sa 52, is available in: T. Bąk, ProtoIsaiah in the Sahidic Dialect of the Coptic Language. Critical Edition Based on the Coptic Manuscript sa 52 (M 568) and Other Witnesses (Patrologia Orientalis 251; Turnhout: Brepols 2020). Elaboration of Isa 40 in the article: T. Bąk, Isa 40. Text of Isa 41 available in: T. Bąk, Isa 41. Text of Isa 42:1-44:5 published in: T. Bąk, Isa 42:1-44:5. Text of Isa 44:6-45:25 developed in: T. Bąk, Isa 44:6-45:25.

2 The history and general description of the manuscript is given in Bąk, Proto-Isaiah, 347-361. Description of the entire Pierpont Morgan collection, to which the manuscript sa 52 belongs, in L. Depuydt, Catalogue of Coptic Manuscripts in the Pierpont Morgan Library (CIM 4. Oriental Series 1; Leuven: Peeters 1993) 20-22.

3 See https://atlas.paths-erc.eu/manuscripts/205 [access: 26.03.2020].

4 The verse Isa 46:1 begins at page https://archive.org/stream/PhantoouLibrary/m568\%20Combined\%20\%28Bookmarked\%29\#page/n93/mode/2up [access: 26.03.2020].

5 The beginning of Isa 46:1 on page: http://coptot.manuscriptroom.com/manuscript-workspace/?doc $\mathrm{ID}=622008 \& \mathrm{fbclid}=\mathrm{IwAR} 3 \mathrm{TDeECwvoRaXyDc0EgFJU6uZ9dFQ5ynkvee0FXCgEV2hK73AQv}$ DM_XL8 [access: 26.03.2020].

6 See. $\overline{h t t p s: / / c o p t o t . m a n u s c r i p t r o o m . c o m / m a n u s c r i p t-w o r k s p a c e / ? d o c I D=622008 ~[a c c e s s: 26.03 .2021] . ~}$ 
course can be easily associated with the above-mentioned sa 52 , belonging to a completely different Karlheinz Schüssler system.

According to Alin Suciu's observation, the Coptic manuscripts containing the text of the Book of Isaiah were divided into three parts. The first one contained verses from 1:1 to 30:5, the second one included verses from 30:6 to 46:13, and the third one included verses from $47: 1$ to $66: 24 .^{7}$ Thus, the boundary between the second and third volume runs through the chapters elaborated in this article. The author of the manuscript sa 52 (M 568) was probably aware of the division of the Coptic text of the Book of Isaiah into three parts. Although our manuscript contains the entire book, nevertheless the verse Isa $47: 1$ begins on a new folio bearing number $97 \mathrm{f} .48^{\mathrm{r}}$ (Copt. $\overline{\mathbf{4}}$ ). Since the division of the Coptic text is caused by purely practical reasons ${ }^{8}$ and is not reflected either in the Greek LXX manuscripts or especially not in the Hebrew text, in our article, chapters Isa 46-48 will be treated jointly as part of the Book of Deutero-Isaiah (Isa 40-55).

The numbering of the folios in this study follows the facsimile numbering of the Vatican Library. As the numbering on the Digital Edition of the Coptic Old Testament website does not match the facsimile edition, in order to avoid ambiguity, the original Coptic page numbers will also be used in this article.

This study combines the features of both the diplomatic edition of the manuscript sa 52 (M 568) and a critical edition. In addition to the preferred manuscript sa 52 from the Pierpont Morgan collection, editions of all other available Coptic manuscripts in the Sahidic dialect, which contain at least some of the verses from Isa 46-48, will also be taken into consideration. Markings in the critical apparatus (exclamation mark in superscript: !) will suggest reading closer to the Greek text LXX.

Critical edition and philological analysis of the selected fragment will be carried out in accordance with the order adopted in the elaboration of the earlier chapters of the Book of Isaiah. Therefore, it will include the following elements: 1) general characteristics of the folios of the manuscript sa 52, containing the Isa 46-48 text, 2) a list of manuscripts with the Isa 46-48 text in the Sahidic dialect of the Coptic language, 3 ) a presentation of the Coptic text based on the manuscript sa 52 with considerations for other available witnesses, 4) translation into English, 5) a list of the differences between the Greek LXX text and its Coptic translation, 6) an analysis of the more difficult philological phenomena observed in the Coptic fragment of Isa 46-48.

\footnotetext{
$7 \quad$ A. Suciu, "The Sahidic Tripartite Isaiah: Origins and Transmission within the Coptic Manuscript Culture," APF 66/2 (2020) 392.

$8 \quad$ See Suciu, "Sahidic Tripartite Isaiah," 392.
} 


\section{General Information about the Notation of Isa 46-48 in the Manuscript sa 52}

Chapter 46 of the Book of Isaiah begins in the manuscript sa 52 on folio 95 (f. $47^{\mathrm{r}}$, Copt. $\overline{4 Z}$ ) in line 25 of the right column. Chapter 48 ends on folio 100 (f. $49^{v}$, Copt. $\overline{\mathrm{PB}}$ ) in line 21 of the right column. Therefore chapters 46-48, the elaboration of which is the subject of this article, occupy 10 columns of text in the manuscript sa 52 .

The manuscript sa 52 has survived to our times in a very good condition. There are no major problems with reading the text either. Problems may only arise with single letters, as is the case in e.g., Isa 48:7 (f. $49^{\text {r }}$, Copt. $\overline{\mathrm{Pd}}$, left column, line 28), wherein in the spelling of $\mathbf{x} \epsilon \mathbf{c} \boldsymbol{\epsilon}$ unambiguous reading of $\mathbf{C}$ causes difficulties. Due to smudged ink, it could be read as $\boldsymbol{\epsilon}$ or $\mathbf{O}$.

Just as in the earlier chapters of the Book of Isaiah, the columns of the text in Isa 46-47 are not overly regular. They are roughly the same length, although the number of text lines is different and ranges from 32 (both columns on folio f. $48^{v}$, Copt. $\overline{\mathbf{P}}$ ) to 38 (f. $47^{\mathrm{v}}$, Copt. $\overline{\mathbf{4 N}}$, the left column). On folio f. $48^{\mathrm{v}}$, Copt. $\overline{\mathbf{P}}$, especially in its upper part, one can see delicately marked horizontal lines which are to help in the even notation of the text. They run across the entire width of the folio so that the same number of text lines is found in both columns.

Since the width of the columns is not equal, the number of letters in each line differs considerably. The greatest number of letters, which can be seen with even a general look at folio f. $47^{\mathrm{v}}$ (Copt. $\overline{\mathbf{4 N}}$ ), is found in individual lines of Isa 46:4 (the left column, lines from 12 to 18). Five of the eight lines in this fragment begin with the same word ANOK. Each letter $\boldsymbol{d}$ is enlarged here and extends beyond the column. Additionally, next to each $\mathbf{d}$, the coronis sign was placed. It is therefore clear that the author of the sa 52 manuscript aims to achieve a logical division of the content in Isa 46:4.

On folio f. $47^{\mathrm{v}}$ (Copt. $\overline{\mathbf{4 N}}$ ) the ending of both columns coincides with the content ending of individual verses. For the left column, it is the text of Isa 46:7, and for the right column it is Isa $46: 13$, being simultaneously the end of the entire chapter. Although the author of the sa 52 manuscript had not yet learnt of biblical text division into chapters and verses, the ending of the columns on folio f. $47^{\mathrm{v}}$ may indicate an intention to organize the content logically.

On page 100 (f. $49^{\mathrm{v}}$, Copt. $\overline{\mathrm{PB}}$ ) under the last line of the text in the left column, which ends in the verbal form NNдвоTK, the word $€$ СО $\lambda$ was added. Adding only one word in a column numbering 32 lines seems all the more surprising when we take into account the fact that the adjacent column consists of 34 lines. The scribe, instead of just one word, could have thus added an entire line. A single word added under the column may once again confirm the lack of diligence in the writing of the manuscript. This example shows that the author of the codex 
did not plan an even distribution of the text before. He wrote in quite a spontaneous manner, not caring about the precise width of the columns or the equal number of lines written down.

The shape of the letters throughout the sa 52 codex is fairly identical and proves that one person was the author of the manuscript. From time to time, enlargement of some letter which is unnecessary or difficult to justify can be observed. The verse of Isa 47:10 (f. $48^{\mathrm{v}}$, Copt. $\overline{\mathrm{P}}$, line 4 of the left column) may be an example of this; the last letter T, being part of the form MNT-, is considerably enlarged. In some places, e.g., Isa 48:11 (f. $49^{r}$, Copt. $\overline{P d}$, the right column, line 14) the horizontal part of the letter T was elongated. ${ }^{9}$

Some letters are overly elongated as well. The letter $\sigma$, the upper part of which is quite often extended over the two consecutive letters, could be an example thereof. This can be seen, for instance, on folio f. $48^{v}$ (Copt. $\left.\bar{P}\right)$ in lines 15 and 16 of the left column, in the word бмбом.

The author of the manuscript sa 52 writes down the so-called nomina sacra correctly, employing abbreviations commonly used in the Coptic language. The horizontal line is not always written down precisely. It can be observed, for example, in the word $\Pi \overline{\mathrm{IH} \lambda}$, in which the horizontal line is sometimes extended to the right: $\overline{\mathrm{IIH} \lambda} \cdot{ }^{10}$ In the same word, the line on the right is at times too short: $\overline{\Pi \mathrm{IH}} \lambda .{ }^{11}$ It may also be too long on the right, appearing above the article: $\mathbf{M} \overline{\mathrm{IIH}} \lambda .{ }^{12}$

In the text of Isa $48: 12$ (f. $49^{\text {r }}$, Copt. $\overline{\mathrm{Pd}}$, the right column, line 18) the horizontal line above the letters $\Pi \mathrm{IH} \lambda$ was written down doubly. One line, in black, is placed exactly above the letters $\operatorname{mIH} \lambda$. The other one (in red) starts above the preceding letter $\omega$, which is a part of the conjunction $\mathbf{d} \gamma \omega$, and then is extended above the letters $\mathrm{TIH}$. It can be seen that it was added later, and not in a precise manner.

The second nomina sacra written down without too much precision is $\overline{\pi N d}$ ("spirit"). On page 100 (f. 49v, Copt. $\overline{\mathbf{4 B}}$, the left column, line 14), the expression $\Pi € \overline{4 \Pi N d}$ ("his spirit") is found, in which the horizontal line begins already above the letter $\mathbf{4}$.

In line with the current way of notation, the author of the manuscript sa 52 sometimes uses an abbreviated way of noting down the final letter $\mathbf{N}$, in the form of a horizontal line in superscript. It is observable in Isa 46:13 (f. $47^{\mathrm{v}}$, Copt. $\overline{4 N}$, the right column, line 30 ), where the first word was written as $\mathbf{2} \ddot{i} 2 \bar{\omega}$. Of course, the "full" notation is $\mathbf{\lambda} \ddot{\mathbf{I}} 2 \boldsymbol{\omega} \mathbf{N}$. In our edition, the final "abbreviated" $\mathbf{N}$ is written in parenthesis: $\operatorname{diz} \boldsymbol{i}(\mathbf{N})$.

9 Similarly, in the same column in line 21, and also on page f. $49^{\mathrm{v}}$ (left column, line 3 ) in the expression dïmoYT€ („I have called”).

$10 \quad$ See e.g. f. $47^{\mathrm{v}}$ (Copt. $\left.\overline{4 \mathbf{N}}\right)$, left column, line 7.

11 See e.g. f. $47^{\mathrm{v}}($ Copt. $\overline{4 N})$, right column, line 36 ; similarly on p. $48^{\text {r }}$ (Copt. $\left.\overline{4 \Theta}\right)$, left column, line 28.

12 See f. $49^{v}$ ( Copt. $\left.\overline{P B}\right)$, left column, line 18. 
An unusual phenomenon can be observed in Isa 47:1 (f. $48^{\mathrm{r}}$, the left column, line 5). Above the final vowel $\omega$ of the word Твдвү $\lambda \omega$, a horizontal line was

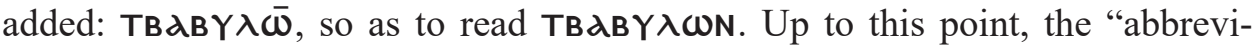
ated" notation of the consonant $\mathbf{N}$ has not appeared in the middle of a text line anywhere in the sa 52 manuscript. It is worth noting, when discussing this verse, that in the electronic transcription of the sa 52 manuscript found on the website of the Digital Edition of the Coptic Old Testament, the words 2MOос Твдвү $\lambda \omega \bar{N}$

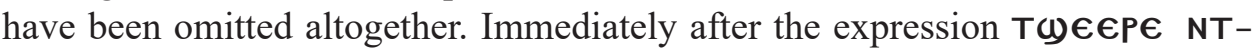

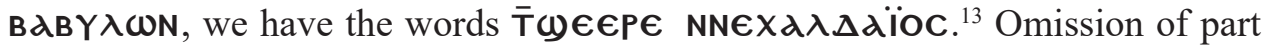
of the manuscript results in incorrect line numbering in the text. The electronic version suggests that there are 33 lines in the left column when, in actual fact, there are 34 of them.

The author of the manuscript left out individual letters in few places. An example may be furnished by the proper name $X \lambda \lambda \Delta \Delta d I O C$ ("Chaldeans"), which was written as $X \lambda \Delta d$ IOC on folio f. $49^{\mathrm{v}}$ (the left column, line 2).

In some parts of the manuscript, it is visible that letters were complemented. This phenomenon can be observed in Isa 46:6 (f. 47v Copt. $\overline{4 N}$, the left column, line 25), where in the word $\mathbf{a} Y \boldsymbol{\theta N O}$, the letter $Y$ was added above the text line. The shape of the letter differs slightly from the handwriting used by the scribe. His letter $Y$ is a bit more elongated, with the bottom part noticeably emboldened. The shade of the ink of the added letter is, however, identical to the $a$ previously written. Therefore, it is difficult to decide whether the added $Y$ comes from the author of the sa 52 manuscript or whether it was added later. In our edition, the word $\alpha$ Y $\Theta N O$ was written as $\mathbf{A} \backslash \mathrm{Y} / \Theta N O$.

In the verse Isa $48: 15$ (f. $49^{v}$, Copt. $\overline{P B}$, the left column, line 5), in the expression $\mathbf{N}$ T€ $\mathbf{4}$ ïH ("his way"), the letter $\mathbf{4}$ was added above the text. The colour of the ink does not reveal either if it comes from the author of the sa 52 manuscript. Only the shape of the letter, and its elongated vertical part in particular, could indicate a later origin from somebody else.

In the verse Isa $48: 19$ (f. $49^{v}$, Copt. $\overline{\mathrm{PB}}$, the left column, line 28), in the word пєКСпєРмд ("your offspring") the letter $\mathrm{K}$ was added above.

In the verse Isa $46: 12$ (f. $47^{\mathrm{v}}$, Copt. $\overline{\mathbf{4 N}}$, the right column, line 29), a fairly large gap is visible between the word N€тоҮнY and $€$ во $\lambda$. Probably four or five letters which were originally there have been erased.

The gap left after the erased letters is also found on p. 100 (f. $49^{\mathrm{v}}$, Copt. $\overline{\mathrm{PB}}$ ) at the beginning of text lines 11 and 12 in the right column. In line 12, in front of the letters $\mathrm{K} \omega \mathrm{B}$, belonging to the name $\mathrm{I} \mathrm{\alpha} \mathrm{K} \omega_{\mathrm{B}}$, one can even see traces of the letters: oco. However, it is difficult to determine which word they belong to. In

$13 \mathrm{http} / /$ coptot.manuscriptroom.com/manuscript-workspace/?docID=622008\&fbclid=IwAR3TDeEC wvoRaXyDc0EgFJU6uZ9dFQ5ynkvee0FXCgEV2hK73AQvDM_-XL8 [access: 10.04.2020]. 
the vicinity of this area the remains of many other Coptic letters are visible. It cannot be ruled out that there may have been another Coptic text originally under the script of the Book of Isaiah.

Also in the verse Isa 47:6 (f. 48r , Copt. $\overline{\mathbf{4}}$, right column, line 2) in the first word $\mathrm{AC \omega} \omega 4$ a fairly large space can be seen between the first two letters. The width of the empty space may indicate the removal of one letter and the extension of the lower part of $\mathbf{d}$ towards $\mathbf{C}$ in order to fill in the empty space. The colour of the ink may indicate corrections made by the author of the manuscript.

In Isa 48:1 (f. 48v , Copt. $\bar{P}$, right column, line 25) the first letter of the negation dN shows traces of a correction, which was made quite negligently. The scribe simply wrote the letter $\mathrm{d}$ over what had been drawn erroneously.

In the sa 52 manuscript one can see a tendency to duplicate the letter $\mathbf{N}$. This is especially conspicuous in the places where the previous word ends with the letter $\mathbf{- N}$ and the following one begins with the letter $\mathbf{M}-$. Between the letters $-\mathbf{N}$ and $\mathbf{M}$ - an added letter $\mathbf{N}$ - can be occasionally seen. This phenomenon most likely stems from phonetic considerations and can be observed in the following verses:

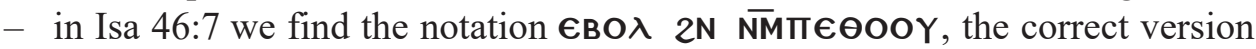
of which should be $€$ BO $\lambda$ 2N $\mathbf{M} \Pi € \Theta 0 O Y$ ("from evils"),

- in Isa 46:11 we read $€ B O \lambda 2 \overline{\mathbf{N}} \overline{\mathrm{NM} M \boldsymbol{N}} \mathbf{N} \boldsymbol{N} \boldsymbol{d}$, although the correct notation should be $€ B O \lambda 2 \overline{\mathrm{N}} \overline{\mathrm{M}} \mathrm{Md} \mathrm{N} \omega \boldsymbol{\alpha}$ ("from the east").

\section{A List of Manuscripts with the Text of Isa 46-48 in the Sahidic Dialect of Coptic}

Fragments of chapters 46-48 of the Book of the Prophet Isaiah may be found in several other manuscripts, which are not as complete as sa 52. In the nomenclature of manuscripts, priority will be given to the markings in Karlheinz Schüssler's study. ${ }^{14}$ Whenever feasible, references to electronic collections will also be provided. At least some verses of the text of Isa 46-48 are found in the following manuscripts:

Sa 41.17: a manuscript constituting a fragment $32 \times 28 \mathrm{~cm}$ in size (the socalled membra disjecta) of a two-part codex containing texts of several Old Testament prophets. ${ }^{15}$ The folio being of interest to us is kept in the National Library

14 K. Schüssler, Das sahidische Alte und Neue Testament (Biblia Coptica; Wiesbaden: Harrasowitz 1995-2012).

15 Cf. Schüssler, Sa 21-48, 74-76, 81. The manuscript is also mentioned in W.C. Till, "Die Coptica der Wiener Papyrussammlung," ZDMG 95 (1941) 204, and also in W.C. Till, "Papyrussammlung der Nationalbibliothek in Wien. Katalog der koptischen Bibelbruchstücke. Die Pergamente," ZNW 39 (1940) 16 (No. 52). 
in Vienna under the reference number: Wien, ÖNB, K 9397. It contains the text of Isa 45:21b-46:13a. In this article, attention will be focused on Isa 46:1-13a. An edition of the sa 41.17 manuscript, a handwritten one, was developed by Wessely. ${ }^{16}$ The parchment was also placed on the Arthur Vaschalde's list, ${ }^{17}$ where it received the designation SER $220 .{ }^{18}$

Sa 48: A papyrus codex, stored in the Bibliotheca Bodmeriana in Cologny in the Canton of Geneva, with designation Papyrus Bodmer XXIII. It belongs to a large collection of manuscripts found in 1952, probably in the Egyptian town of Dishna ${ }^{19}$ located in Upper Egypt, near the famous Nag Hammadi. ${ }^{20}$ It is the last part of a three-volume papyrus codex. It consists of 82 folios with relatively small dimensions of $21 \times 13.5 \mathrm{~cm}$. There is one column of text on each page. The codex is preserved in a fairly good condition. ${ }^{21}$ It contains the text of Isa 47:1-51:17 and Isa 52:4-66:24. The only missing folios, numbered $\overline{\mathrm{Kd}}$ and $\overline{\mathrm{KB}}(21$ and 22$)$, contain verses Isa 51:18-52:4. Beginning the codex from the verse Isa 47:1 is not accidental. The manuscript contains the third part of the Book of Isaiah, which according to the Coptic division began at this very place. The author of the codex writes about it straightforwardly on the title folio: $\Pi[\mathrm{M} \Theta] 2 \omega$ OMNT $\overline{\mathbf{M}} \mathbf{M}[\boldsymbol{\Theta P}]$

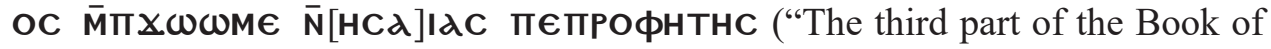
the Prophet Isaiah"). ${ }^{22}$

The dating of the manuscript, based on its external appearance, palaeographical analysis, and language features, points to 4 th century; ${ }^{23}$ more precisely to the years $375-450 .{ }^{24}$ On account of its early origins, it is an invaluable aid in the edition of parts of both the Book of Deutero-Isaiah and the entire Book of

16 C. Wessely, Griechische und koptische Texte theologischen Inhalts (Studien zur Palaeographie und Papyruskunde 15; Leipzig: Haessel 1914) IV, no. 220 e-f.

17 A. Vaschalde, "Ce qui a été publié des versions coptes de la Bible," $R B 29$ (1920) 249.

18 The abbreviation SER is an abbreviation of the original Viennese collection to which the manuscript belonged: Sammlung Erzherzog Rainer (cf. A. Vaschalde, "Ce qui a été publié des versions coptes de la Bible," RB 16 [1919] 223).

19 There is no certainty as to where this manuscript was found. Following Alin Suciu ("Sahidic Tripartite Isaiah," 378), one can only state: "This manuscript is [...] said to have been found late in 1952 near Dishna."

20 The history of the discovery of the manuscripts referred to as "Dishna Papers" in: J.M. Robinson, "The Manuscript's History and Codicology," The Crosby-Schøyen Codex MS 193 in the Schøyen Collection (ed. J.E. Goehring) (CSCO. Subsidia 85; Louvain: Peeters 1990) XIX-XLVII. Manuscript with the text of Isa 47:1-66:24 is listed here under number 14 on p. XXIX. A more contemporary presentation of «Dishna Papers» is elaborated in J.L. Fournet, "Anatomie d'une bibliothèque de l'Antiquité tardive: l'inventaire, la faciès et la provenance de la 'Bibliothèque Bodmer'," Adamantius 21 (2015) 8-40.

21 The facsimile of the codex available in electronic form on the website: https://bodmerlab.unige.ch/fr/ constellations/papyri/barcode/1072205362?page=48 [access: 03.06.2020].

22 See Suciu, "Sahidic Tripartite Isaiah," 380.

23 Schüssler, $\mathrm{Sa} 21-48,106$.

24 See https://atlas.paths-erc.eu/manuscripts/40 [access: 03.06.2020]. 
Trito-Isaiah. ${ }^{25}$ The manuscript was edited by Rodolphe Kasser in $1965 .{ }^{26}$ Papyrus Bodmer XXIII is placed on the Peter Nagel list ${ }^{27}$ and was marked in the electronic database as CLM 40 ${ }^{28}$ and LDAB 108542. ${ }^{29}$

Sa 108 : the manuscript is a bilingual (Coptic-Arabic) lectionary consisting of 189 folios containing readings for Holy Week. It comes from the White Monastery in Sohag. Today it is kept in the Vatican Library. The Coptic text is the dominant one. The part in Arabic is merely its translation, not always a faithful one. ${ }^{30}$ The readings are composed of texts from both the Old and New Testament. A fairly large number of fragments comes from the Book of Isaiah. ${ }^{31}$ Each day of Holy Week was divided into ten canonical hours, half of which were celebrated during the day, while the other half at night. The text Isa 48:1-6 was read on Wednesday during the sixth canonical hour. ${ }^{32}$

Since it is a paper codex, its dating falls within a later time interval and is placed by scholars between the 12th and 14th centuries. ${ }^{33}$ The text of Isa 48:1-6 was edited

25 More information in: Schüssler, Sa 1-20, 106; R. Kasser, Papyrus Bodmer XXIII. Esaïe XLVII, 1-LXVI,24 (Cologny - Genève: Bibliotheca Bodmeriana 1965) 7-33.

26 Kasser, Papyrus Bodmer XXIII.

27 P. Nagel, "Editionen koptischer Bibeltexte seit Till 1960," APF 35 (1990) 60.

28 See https://atlas.paths-erc.eu/manuscripts/40 [access: 03.06.2020].

29 See https://www.trismegistos.org/tm/index.php?searchterm=LDAB\%20108542 [access: 03.06.2020].

30 A detailed description of the lectionary in: A. Ciasca, Sacrorum Bibliorum fragmenta copto-sahidica Musei Borgiani iussu et sumptibus S. Congregationis de Propaganda Fide studio P. Augustini Ciasca ordinis Eremitarum S. Agostini edita (Roma: Typis S. Congregationis de Propaganda Fide 1885-1889) I, XXVI-XXVII (manuscript presented with no. IC); G.W. Horner, The Coptic Version of the New Testament in the Southern Dialect, Otherwise Called Sahidic and Thebaic, with Introduction, Critical Apparatus, and Literal English Translation. III. The Gospel of S. John (Oxford: Clarendon 1911) III, 360, 383 (on the list of manuscripts on page 360 the lectionary is marked as $m l$, while in the description of manuscripts on page 383, as Vatican 99); H. Hyvernat, "Étude sur les versions coptes de la Bible. II. - Ce qui nous est parvenu des versions égyptiennes," RB 5 (1896) 548-549 (as M. Borg. Cod. Sah. 99. C. A. - Bombycin); A. Rahlfs, Die alttestamentlichen Lektionen der griechischen Kirche (MSU 5; Berlin: Weidmann 1915) 69; F.J. Schmitz - G. Mink, Liste der Koptischen Handschriften des Neuen Testaments. I. Die sahidischen Handschriften der Evangelien (ANTF 15; Berlin - New York: De Gruyter 1991) 2/2, 1084-1086 (as sa 16L); Schüssler, Sa 93-120, 49-69; G. Zoega, Catalogus codicum copticorum manu scriptorum qui in museo Borgiano velitris adservantur (Roma: Typis Sacrae Congregationis de Propaganda Fide 1810) 189-192, 196-203 (the manuscript presented as in the edition of Augustini Ciasca with no. 99, written as XCIX and IC; on page 189 there is an error: instead of CXIX there should be XCIX).

31 A detailed listing of verses from the Book of Isaiah is given in: Schüssler, $\mathrm{Sa}$ 93-120, 50-51.

32 Schüssler, Sa 93-120, 56.

33 Henri Hyvernat ("Étude II," 548-549) supports the earliest dating falling within the period of the 12th/13th centuries. George W. Horner (Coptic Version of the New Testament, III, 383) specifies the age of the lectionary as "not earlier than XIII"; Balestri moves it to the 13th or 14th century (P.J. Balestri, Sacrorum Bibliorum Fragmenta Copto-Sahidica Musei Borgiani. III. Novum Testamentum [Roma: Typographia Polyglotta S. C. de Propaganda Fide 1904] LXI); Ciasca (Sacrorum Bibliorum fragmenta, I, XXVII) advocates the end of the 14th century; Alfred Rahlfs (Die alttestamentlichen Lektionen, 163) speaks of the year c. 1400. 
by Amélineau ${ }^{34}$ and Ciasca, where it is designated as IC. ${ }^{35}$ There are two differ-

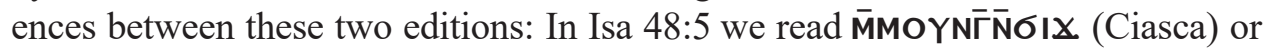
MMONГ NбIX (Amélineau), in Isa 48:6 we find the form $\overline{\mathbf{M}} \boldsymbol{\epsilon} \epsilon \mathbf{T} \overline{\mathbf{N}} \epsilon$ ìm $€$ (Ciasca) or мпєтєтNє Iмє (Amélineau). In our edition, the Ciasca edition will be adopted.

CLM 3469: a parchment codex, discovered by a Polish archaeological mission in 2005 near the tomb number 1152 in the area of the Theban Necropolis in the village of Sheikh Abd el-Qurna. It suffered considerable damage from the effects of fire. It originally contained the text of Isaiah beginning with Isa 47:1. To this day, 49 heavily frayed folios have survived -47 of which are written in twocolumn text. The three initial codex folios have undergone complete obliteration (pp. 1-6), containing Isaiah 47:1-14a. Often, only minute passages can be read on the remaining folios. In the text of Isa 47:14b-48:22 being of interest to us, only two verses (48:9.12) have been preserved in their entirety. The remaining ones are incomplete and five verses (48:2.5 6.15.22) have been completely destroyed.

At the end of the codex there is a fragmentarily preserved inscription:

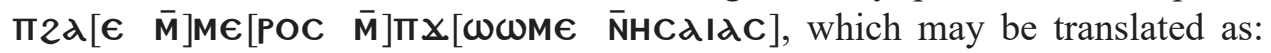
"The last part [of the Book of Isaiah]." It most probably contained the text of Isa 47-66. The penultimate preserved codex folio was decorated with a cross on the recto page and a drawing of a vase with two birds on the verso page. The last folio was originally blank. At a later time, fragments of the Sahidic version of Acta Petri (Clavis Coptica 0026) ${ }^{36}$ were written on both of the last folios.

Codex 3469 is dated to the 7th-8th centuries. It was first stored in Alexandria after its discovery in 2005. It has been stored in the Coptic Museum in Cairo since 2013, where it has been catalogued as Cairo, CM, Inv. No. 13446. In the electronic database of manuscripts, it has been referred to as CLCM $3469^{37}$ and LDAB $113915 .{ }^{38}$ In the Digital Edition of the Coptic Old Testament project, it is listed bearing the number sa 2028. ${ }^{39}$ The reconstruction of the text, which was used in this study is also available there. ${ }^{40}$

P. Lond. Copt. 46: papyrus fragment - written on both sides. It has already been described in an article dedicated to Isa $42: 1-44: 5 .^{41}$ The manuscript con-

34 É. Amélineau, "Fragments de la version thébaine de l'Écriture (Ancien Testament)," Recueil de travaux relatifs à la philology et à l'archéologie égyptiennes et assyriennes 9 (1887) 125.

35 Ciasca, Sacrorum Bibliorum fragmenta, II, 240.

36 See Suciu, "Sahidic Tripartite Isaiah," 380-383.

37 See https://atlas.paths-erc.eu/manuscripts/3469 [access: 28.06.2021].

38 See https://www.trismegistos.org/text/113915 [access: 28.06.2021].

39 Since the manuscript markings introduced by Karlheinz Schüssler are often used in this article, in order not to create additional confusion, we prefer to treat the Qurna codex not as sa 2028 but as CLM 3469.

40 Isa $47: 14 b$, which is the first available verse, is available on the website: https://coptot.manuscriptroom.com/manuscript-workspace/?docID $=622028$ [access: 28.06 .2021$]$.

41 T. Bąk, Isa 42:1-44:5, 231-232. 
tains the text of Isa 43:4-6.11. Eric O. Winstedt, who conducted the edition of the papyrus ${ }^{42}$ reports that in the same glass case there are other passages which belong to the same manuscript, one of which contains verses Isa 47:3-5.10. ${ }^{43}$ The remaining ones are described as too small and too damaged to allow for reading any text from them. ${ }^{44}$ Winstedt's edition should be approached with a great caution, because, as he writes himself, "I reproduce what I thought I could see of it, but most of the letters are quite uncertain, and I cannot identify it." 45

The papyrus was not elaborated in Schüssler's edition. However, it is on the Vaschalde's list, where it was designated as BMC 46. ${ }^{46}$ This designation refers to the number under which the manuscript was described by Crum. ${ }^{47} \mathrm{In}$ the electronic directory of the Leuven Database for Ancient Books, the manuscript was catalogued as LDAB 107917. ${ }^{48}$ There, the manuscript was also dated to the 4 th- 5 th century.

When analysing the text in Winstedt's edition, it is difficult to agree with the opinion that the verse 47:3 belongs to the manuscript of P. Lond. Copt. 46. It is possible to identify only one letter $\Pi$, additionally marked as poorly visible. Therefore, only three verses will be included in the tabular summary below: Isa 47:4-5.10.

P. Monts. Roca 720: a fragment of parchment of an unknown origin. It was part of the private collection of a Catalan priest, Fr. Ramón Roca-Puig. Currently, it is stored at Montserrat Abbey, Spain. First time it was identified and described in an article by A. Suciu. ${ }^{49}$ It includes a small fragment of Isa 48:4b-15a and may be from a slightly earlier period than the CLCM 3469 mentioned above. Number 5 that was preserved on the recto page of the parchment, allows one to conclude that the preserved manuscript belonged to a larger codex that contained the third part of the Book of Isaiah (Isa 47-66). ${ }^{50}$ The manuscript has not been edited yet and will not be included in this study.

\footnotetext{
42 E.O. Winstedt, "Some Unpublished Sahidic Fragments of the Old Testament," JTS 10 (1909), 247.

43 Winstedt, "Some Unpublished Sahidic Fragments," 247.

44 Winstedt, "Some Unpublished Sahidic Fragments," 248.

45 Winstedt, "Some Unpublished Sahidic Fragments," 247. One should read with great caution, for example, v. 4, in which Eric O. Winstedt reads [ח€NTd 4NA] $\overline{2 M N B \omega}$, while the correct reading, confirmed by the manuscript sa 52 and sa 48 , is: Пడ TNOY $2 \bar{M}$ MMOK.

46 Vaschalde, "Versions coptes de la Bible," 249. Here, we find the information that both Isa 43:4-6 and 47:3.4.5.10 belong to the same manuscript.

47 W.E. Crum, Catalogue of the Coptic Manuscripts in the British Museum (London: British Museum 1905) 13-14. The author includes only Isa 43:4-6 in the manuscript number 46. However, he adds a comment: "There are, I think, other fragments of this MS. in the portfolio Papyrus VIII" (ibidem, 14).

48 See https://www.trismegistos.org/text/107917 [access: 6.06.2020]. See also http://papyri.info/ $\mathrm{dclp} / 107917$ [access: 6.06.2020].

49 Suciu, "Sahidic Tripartite Isaiah," 388-389.

50 See Suciu, "Sahidic Tripartite Isaiah," 389.
} 
In order to illustrate the contents of particular manuscripts better, the occurrence of the verses from Isa $46-48$ is presented in the table where:

- "x" means the occurrence of the whole verse,

- "(x)" means the occurrence of only a fragment of a given verse,

- an empty space in the table means the lack of a given verse in the manuscript. The contents of the manuscripts are as follows:

Isa 46

\begin{tabular}{|l|c|c|c|c|c|c|c|c|c|c|c|c|c|}
\hline & $\mathbf{1}$ & $\mathbf{2}$ & $\mathbf{3}$ & $\mathbf{4}$ & $\mathbf{5}$ & $\mathbf{6}$ & $\mathbf{7}$ & $\mathbf{8}$ & $\mathbf{9}$ & $\mathbf{1 0}$ & $\mathbf{1 1}$ & $\mathbf{1 2}$ & $\mathbf{1 3}$ \\
\hline Sa 41.17 & $(\mathrm{x})$ & $\mathrm{x}$ & $\mathrm{x}$ & $(\mathrm{x})$ & $(\mathrm{x})$ & $\mathrm{x}$ & $\mathrm{x}$ & $(\mathrm{x})$ & $(\mathrm{x})$ & $\mathrm{x}$ & $\mathrm{x}$ & $\mathrm{x}$ & $(\mathrm{x})$ \\
\hline Sa 48 & & & & & & & & & & & & & \\
\hline Sa 108 & & & & & & & & & & & & & \\
\hline $\begin{array}{l}\text { P. Lond. } \\
\text { Copt. 46 }\end{array}$ & & & & & & & & & & & & & \\
\hline
\end{tabular}

\section{Isa 47}

\begin{tabular}{|l|c|c|c|c|c|c|c|c|c|c|c|c|c|c|c|}
\hline & $\mathbf{1}$ & $\mathbf{2}$ & $\mathbf{3}$ & $\mathbf{4}$ & $\mathbf{5}$ & $\mathbf{6}$ & $\mathbf{7}$ & $\mathbf{8}$ & $\mathbf{9}$ & $\mathbf{1 0}$ & $\mathbf{1 1}$ & $\mathbf{1 2}$ & $\mathbf{1 3}$ & $\mathbf{1 4}$ & $\mathbf{1 5}$ \\
\hline Sa 41.17 & & & & & & & & & & & & & & & \\
\hline Sa 48 & $\mathrm{x}$ & $(\mathrm{x})$ & $(\mathrm{x})$ & $(\mathrm{x})$ & $(\mathrm{x})$ & $(\mathrm{x})$ & $\mathrm{x}$ & $(\mathrm{x})$ & $(\mathrm{x})$ & $(\mathrm{x})$ & $(\mathrm{x})$ & $\mathrm{x}$ & $\mathrm{x}$ & $\mathrm{x}$ & $\mathrm{x}$ \\
\hline Sa 108 & & & & & & & & & & & & & & & \\
\hline CLM 3469 & & & & & & & & & & & & & & $(\mathrm{x})$ & $(\mathrm{x})$ \\
\hline $\begin{array}{l}\text { P. Lond. } \\
\text { Copt. 46 }\end{array}$ & & & & $(\mathrm{x})$ & $(\mathrm{x})$ & & & & & $(\mathrm{x})$ & & & & & \\
\hline
\end{tabular}

\section{Isa 48}

\begin{tabular}{|l|c|c|c|c|c|c|c|c|c|c|c|c|c|c|c|}
\hline & $\mathbf{1}$ & $\mathbf{2}$ & $\mathbf{3}$ & $\mathbf{4}$ & $\mathbf{5}$ & $\mathbf{6}$ & $\mathbf{7}$ & $\mathbf{8}$ & $\mathbf{9}$ & $\mathbf{1 0}$ & $\mathbf{1 1}$ & $\mathbf{1 2}$ & $\mathbf{1 3}$ & $\mathbf{1 4}$ & $\mathbf{1 5}$ \\
\hline Sa 41.17 & & & & & & & & & & & & & & & \\
\hline Sa 48 & (x) & $\mathrm{x}$ & $\mathrm{x}$ & $\mathrm{x}$ & $\mathrm{x}$ & $\mathrm{x}$ & $\mathrm{x}$ & $\mathrm{x}$ & $\mathrm{x}$ & $\mathrm{x}$ & $(\mathrm{x})$ & $\mathrm{x}$ & $\mathrm{x}$ & $\mathrm{x}$ & $\mathrm{x}$ \\
\hline Sa 108 & $\mathrm{x}$ & $\mathrm{x}$ & $\mathrm{x}$ & $\mathrm{x}$ & $\mathrm{x}$ & $(\mathrm{x})$ & & & & & & & & & \\
\hline CLM 3469 & $(\mathrm{x})$ & & (x) & $(\mathrm{x})$ & & & (x) & (x) & $\mathrm{x}$ & (x) & (x) & $\mathrm{x}$ & (x) & (x) & \\
\hline $\begin{array}{l}\text { P. Lond. } \\
\text { Copt. 46 }\end{array}$ & & & & & & & & & & & & & & & \\
\hline
\end{tabular}

\begin{tabular}{|l|c|c|c|c|c|c|c|}
\hline & $\mathbf{1 6}$ & $\mathbf{1 7}$ & $\mathbf{1 8}$ & $\mathbf{1 9}$ & $\mathbf{2 0}$ & $\mathbf{2 1}$ & $\mathbf{2 2}$ \\
\hline Sa 41.17 & & & & & & & \\
\hline Sa 48 & $\mathrm{x}$ & $\mathrm{x}$ & $\mathrm{x}$ & $\mathrm{x}$ & $\mathrm{x}$ & $\mathrm{x}$ & $\mathrm{x}$ \\
\hline Sa 108 & & & & & & & \\
\hline CLM 3469 & (x) & (x) & (x) & (x) & (x) & (x) & \\
\hline $\begin{array}{l}\text { P. Lond. } \\
\text { Copt. 46 }\end{array}$ & & & & & & & \\
\hline
\end{tabular}


The above-mentioned tabular summary shows that the complete text of Isa 46-48 appears only in the manuscript sa 52 . This fact gives the strongest support for the need of editing this manuscript. Even if Papyrus Bodmer XXIII (sa 48) serves as invaluable assistance in the reconstruction of a considerable part of the Book of Deutero-Isaiah, the most complete text is currently found in the codex sa 52 !

\section{The Sahidic Text of Isa 46-48}

As in the case of the previous chapters the following signs have been introduced in the edition of the Coptic text:

$<>$ pointy brackets indicating that the text has been completed so that it can be properly understood,

\{\} braces indicate the scribe's redundant letters (frequently being an effect of dittography),

$>\quad$ sign indicating the lack of the given form in the manuscript whose number is given beside it, exclamation mark in superscript suggests a more correct reading,

(N) shows the places in which the letter $\mathbf{N}$, occurring at the end of the line, was signalised by a stroke,

$\backslash$ / sign indicating the letter added subsequently by the scribe above the line,

$\bigwedge \quad$ sign indicating the letter added subsequently by the scribe below the line.

The text of Isa 46-48 in the Sahidic dialect of the Coptic language reads as follows:

\section{Chapter 46}

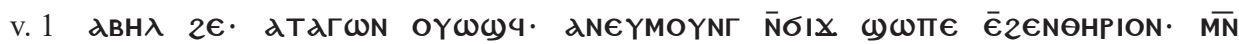

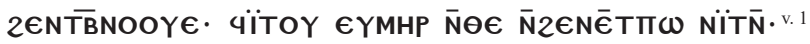

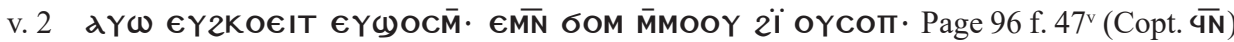

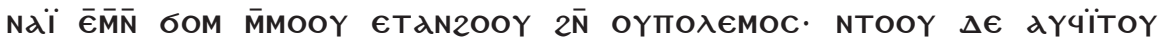

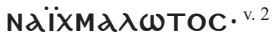

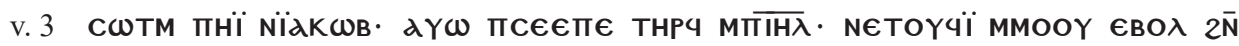

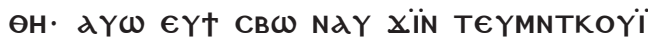




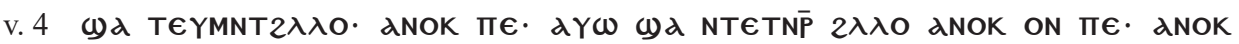

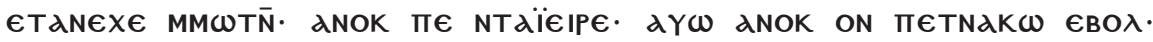

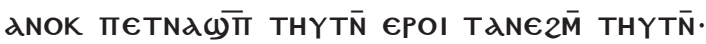

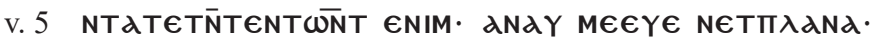

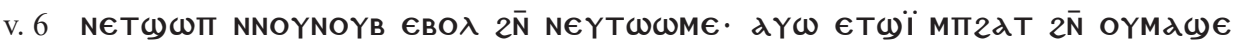

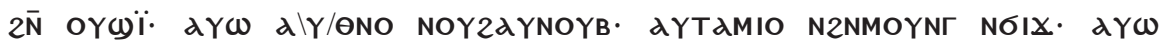

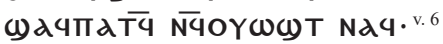

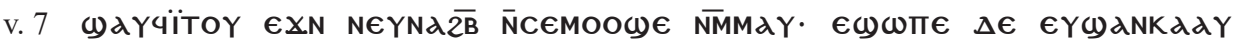

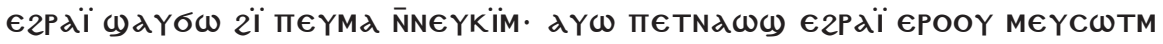

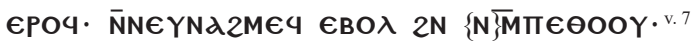

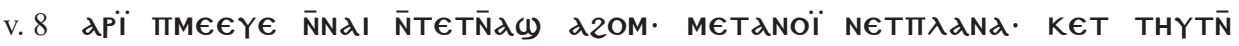
2M TIETN2HT.

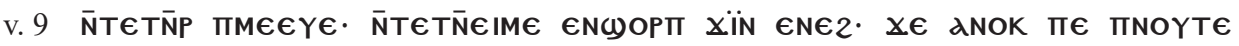

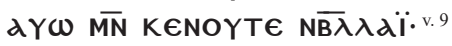

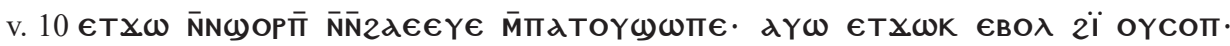

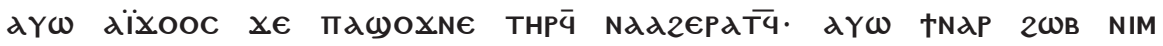

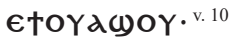

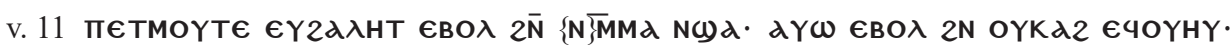

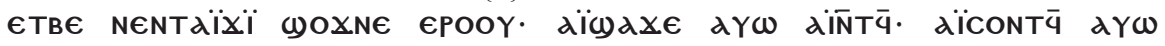

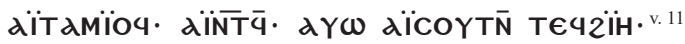

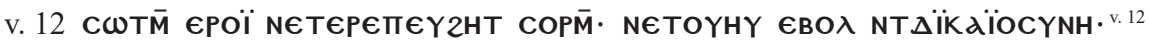

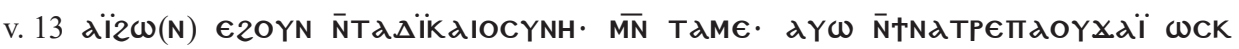

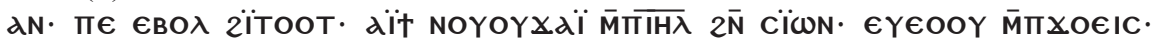

\section{Chapter 47}

v. 1 Page 97 f. $48^{\text {r }}$ (Copt. $\overline{4 \theta}$ ) в

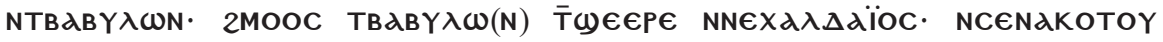

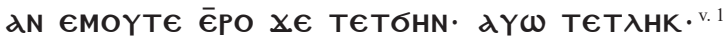

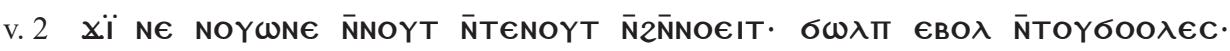

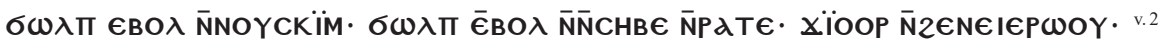

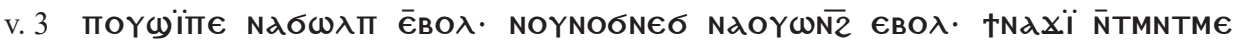

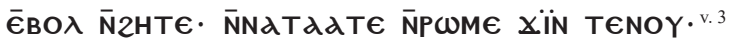

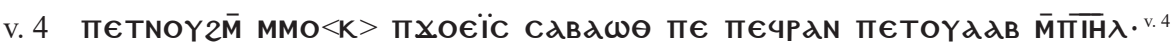

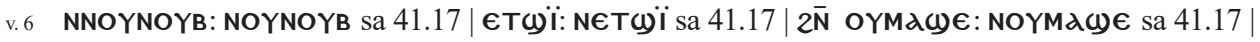

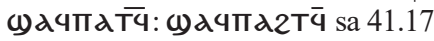

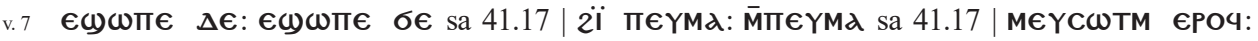

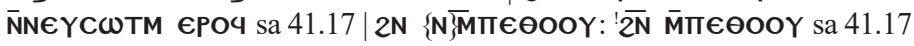

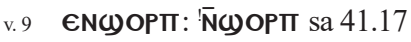

v. $10 \overline{\mathrm{N}} \overline{\mathrm{N}} 2 \lambda \epsilon \epsilon\} \Theta: \overline{\mathrm{MN}} \overline{\mathrm{N}} 2 \lambda \Theta \epsilon\} \Theta$ sa 41.17

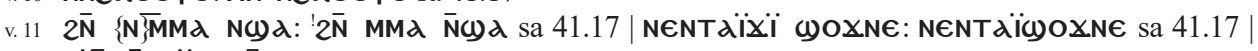

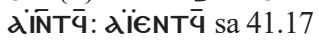

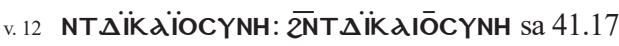

XLVII

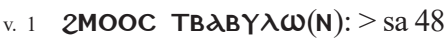

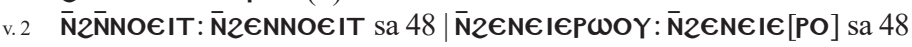

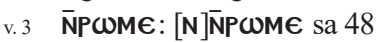

v. 4 MMO $<$ К >: 'MMOK sa 48 
v. 5 2моос $\bar{\epsilon}$ $\overline{N N} €$ YMOYT€ $€$ PO Xï T€NOY $X €$ TOOM NTMNTT€PPO

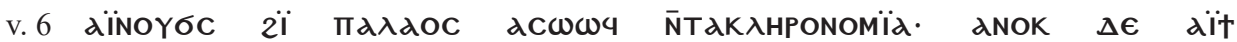

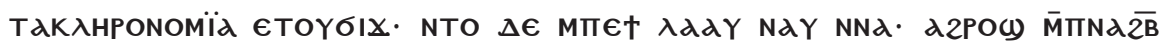

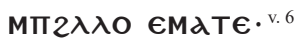

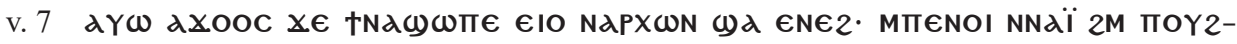

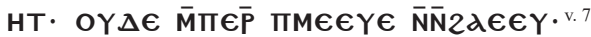

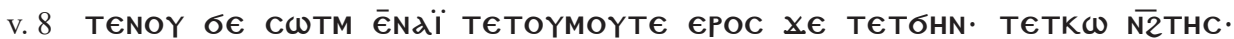

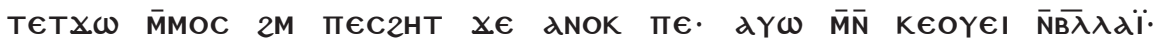

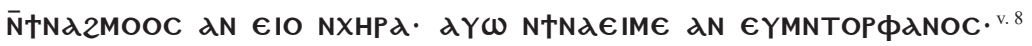

V. 9 TENOY $\Delta €$ TEI CNAY NHY $€ X \omega ~ 2 € N$ OYZOOY NOYWT. TMNTXHPd. MN TMN-

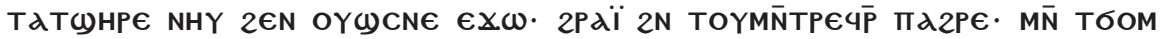
NNOYPE4MOYTE $\cdot$ N2OYO ${ }^{\text {V. } 9}$

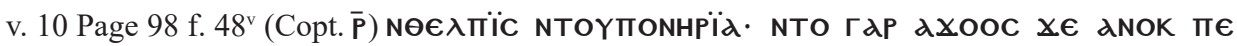

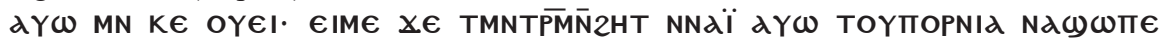

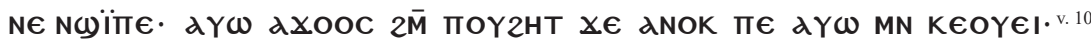

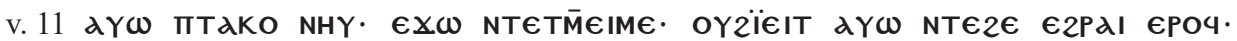

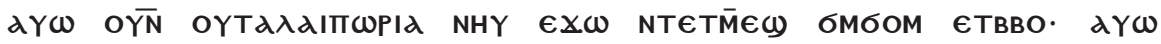

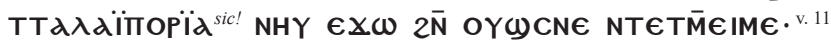

v. 12 d

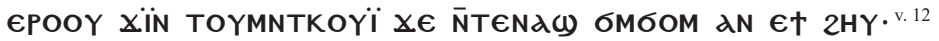

V. 13 d2ICE 2N NOYGOXNE MAPENPEIKA OYNOY NTTE d2EPATOY N̄CETOYXO. NETNAY €NCIOY MAPOYTAMO $X €$ OY N€TNHY $€ 2 P A і ̈ ~ € X \omega \cdot$ v. 13

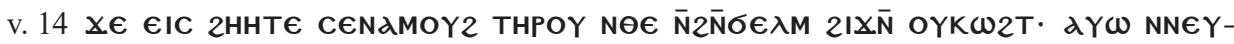

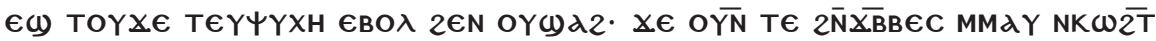
$€ 2 M O O C \in \Pi \epsilon$ СHT $€ X \omega O Y \cdot$ v. 14

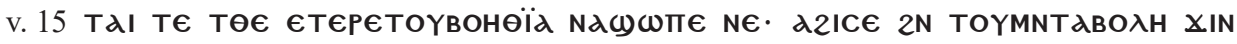

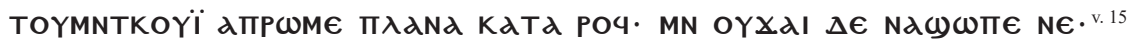

v. 5 2MOос: $x €$ 2MOOC sa 48 |в 46 | $\overline{\mathrm{TTMN}}$ T€PPO: [NTMNTPPO] sa 48

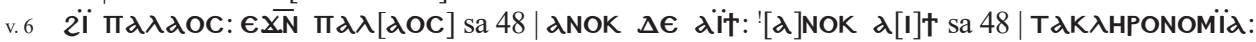

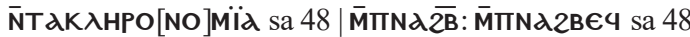

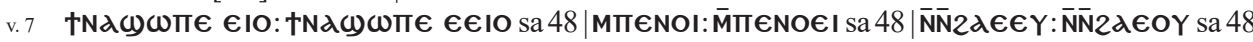

v. 8 גNOK пா: גNOK T€ sa 48 | ЄYMNTOPФANOC: [€]YMNT] [OP]фגNOC sa 48

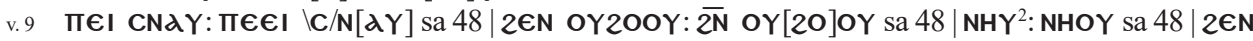

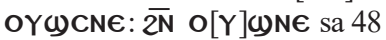

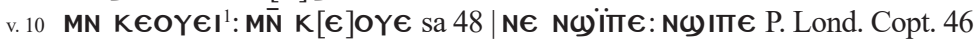

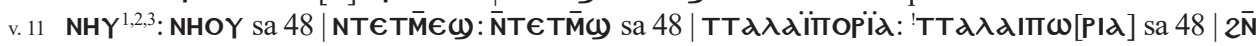
OYWCNE: $2 \bar{N}$ OYWNE sa 48

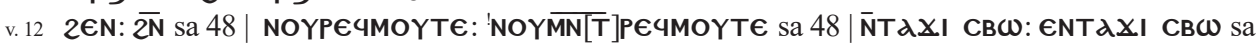

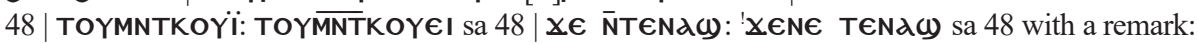
1. $\mathbf{X} \boldsymbol{\epsilon}<\boldsymbol{\epsilon}>\mathbf{N \epsilon} \mid$ aN: $>$ sa $48 \mid$ 2HY: 2HOY sa 48

v. 13 OY NETNHY: OY NE NETNHOY Sa 48

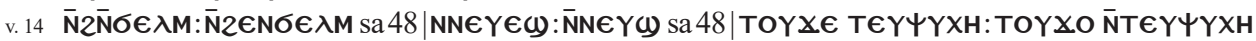

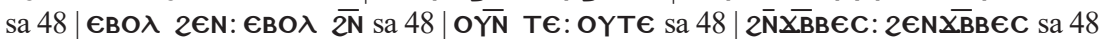

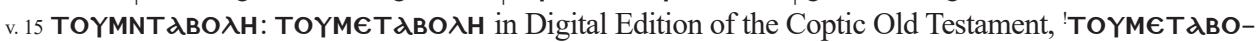
$\lambda$ H sa 48 | TOYMNTKOYï: TOYM[N]TKOY€I sa 48 | OYXגI: OYXג€I sa 48 


\section{Chapter 48}

v. 1 с

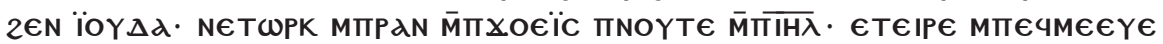

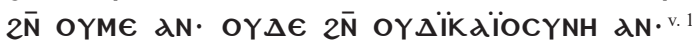

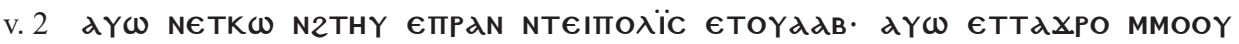

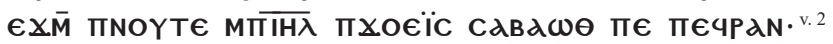

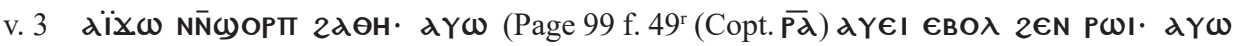

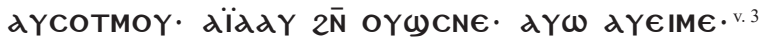

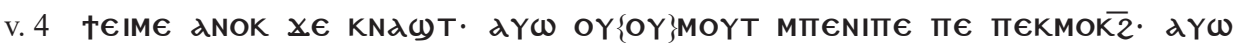
OYZOMNT TE TEKT€2NE ${ }^{\mathrm{v} .4}$

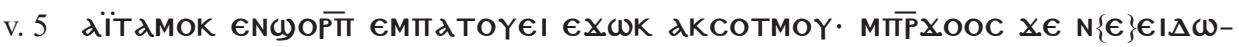

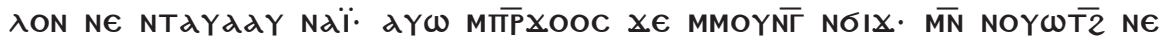
NTAY2WN Nä̈. v. 5

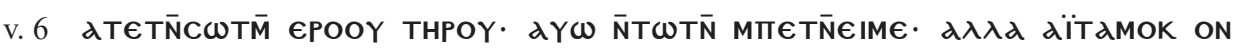

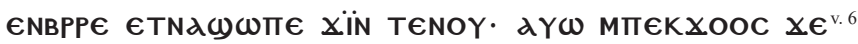

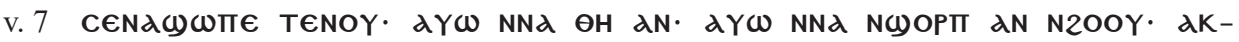

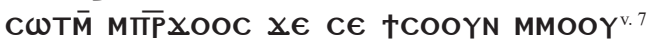

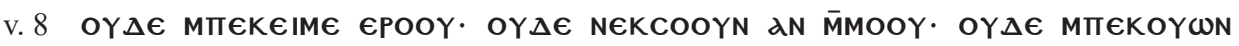

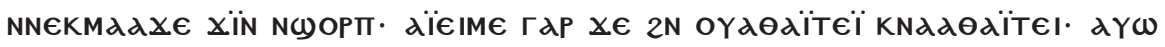

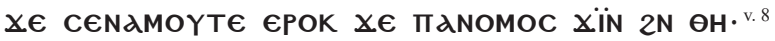

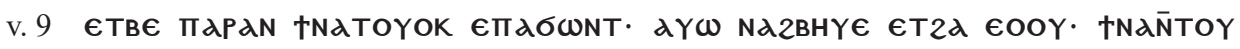
$€ Х \omega K \quad X \in$ NNABOTK $€ B O \lambda \cdot v .9$

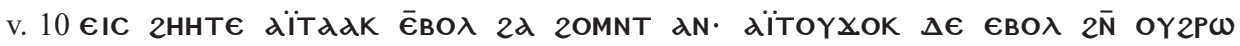
MMNT2HK€・v. 10

\section{XLVIII}

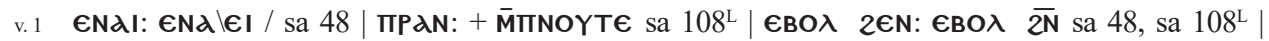

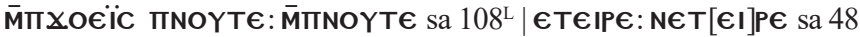

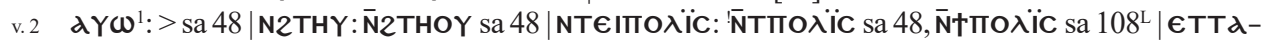

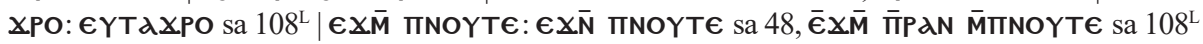

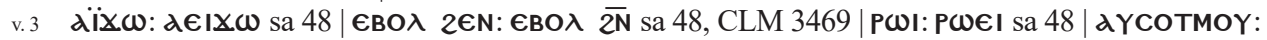

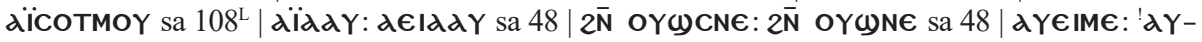

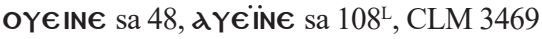

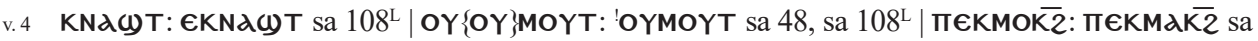
48, sa $108^{\mathrm{L}}$

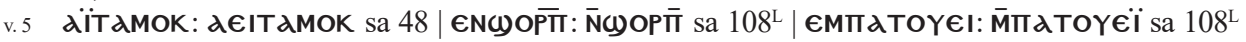

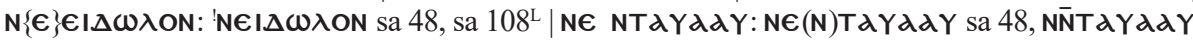
sa $108^{\mathrm{L}} \mid \mathrm{N} \epsilon$ NTdY2WN: NN̄TdY $2 \omega \mathrm{N}$ sa $108^{\mathrm{L}}$

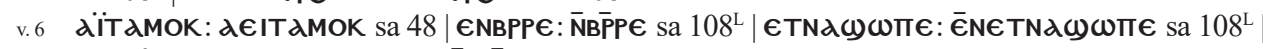
dY $\omega^{2}:>$ sa 48 | MாєKXOOC: $\overline{\text { MTKK}}$ XOOC sa 48

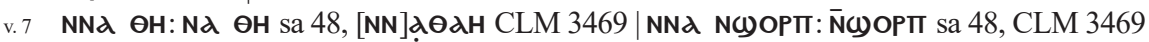

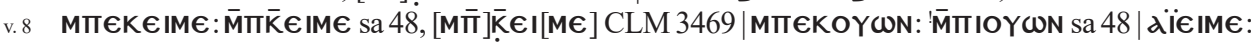

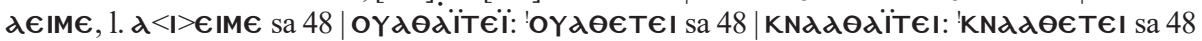

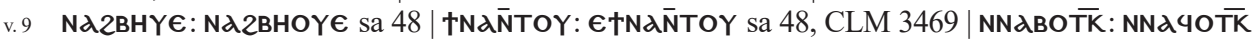
sa 48, CLM 3469

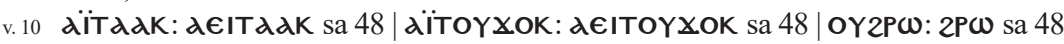




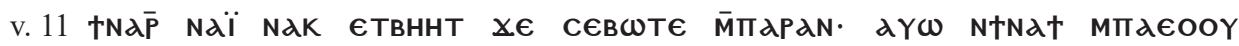
dN $\bar{N} K \in O Y d \cdot{ }^{v} \cdot 11$

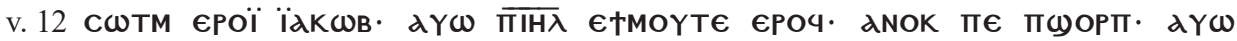
גNOK $\Pi \epsilon \Pi \omega \lambda \in N \epsilon 2^{\cdot v .12}$

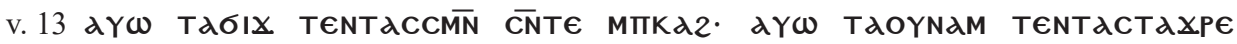
TI૯. †NAMOYT€ €POOY THPOY NC€dZ€ PATOY $2 і ̈$ OYCOT.

V. 14 aYW CENACWOY2 THPOY EZOYN N̈CECWTM. NIM TETNAXW NAY

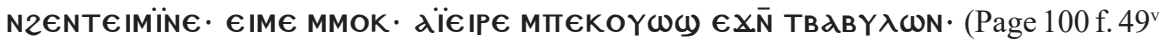

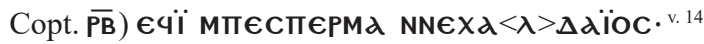

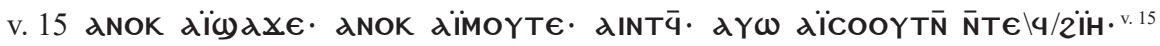

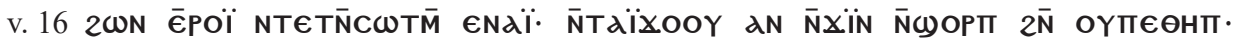

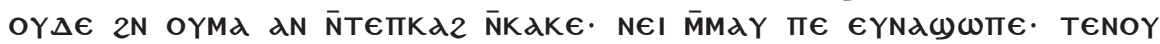

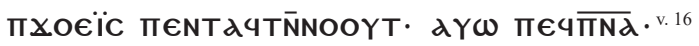

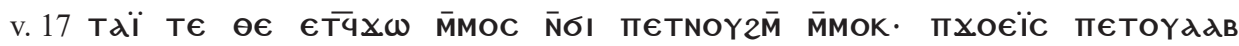

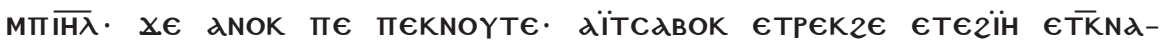
MOOW€ $\overline{\mathrm{N}} 2 \mathrm{HTC}^{\mathrm{v} .17}$

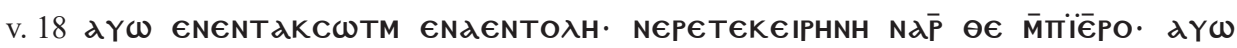

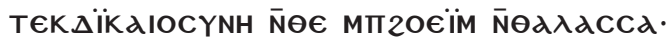

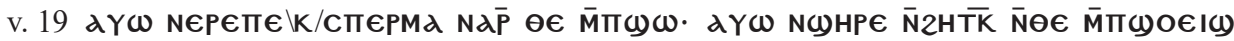
MTKK2. TENOY ON NNABOTK $€ B O \lambda \cdot$ OY $\Delta €$ NNNETEKPAN TAKO MTAM̄TO $\epsilon B O \lambda \cdot{ }^{v} .19$

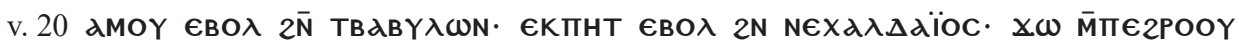

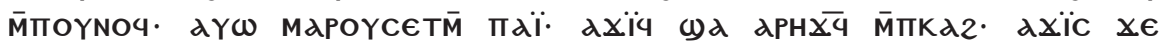

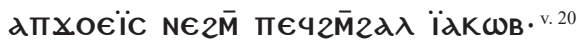

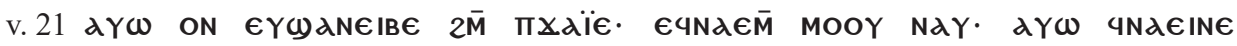

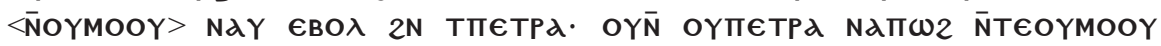

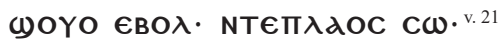

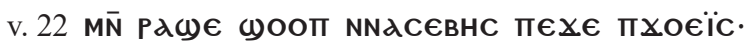

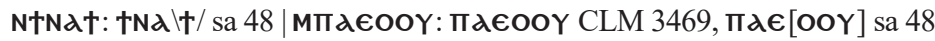

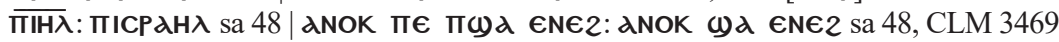

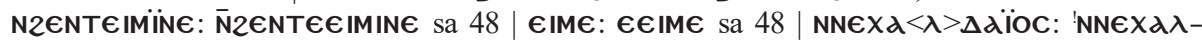
$\triangle d I O C$ sa 48

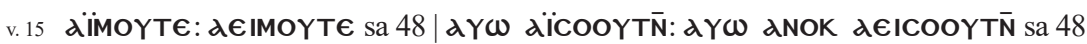

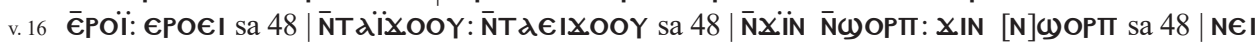

M̄MdY: N€€I M̄MaY sa 48

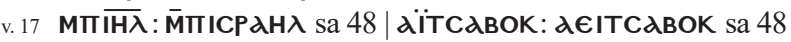

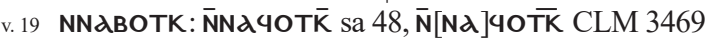

v. 20 dXї: $\mathbf{\lambda X I 4}$ sa 48

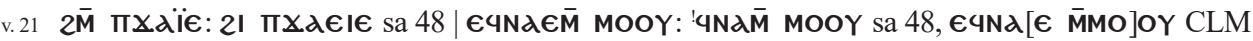

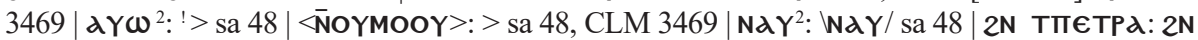

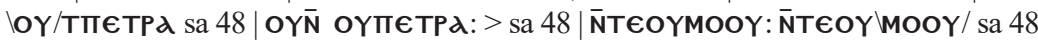




\section{The English Translation of Isa 46-48}

In order to facilitate tracking the differences which occur between the Greek and Coptic texts of Isa 46-48, NETS translation was used for translating into English. ${ }^{51}$ All italicised words immediately indicate differences which occur in the Coptic text. A commentary to each change has been given in footnotes, which refer to even more detailed explanations in the tabular study which is the continuation of this article.

The English translation of Isa 46-48 from the Sahidic dialect of the Coptic language is as follows:

\section{Chapter 46}

v. 1 Bel has fallen; Dagon has been crushed; their graven images have become for beasts and cattle; carry them ${ }^{52}$ bound as burdens ${ }^{53}$ of dung! ${ }^{54}$ [meaning: wear them tied like loads of dung!]

v. 2 They are hungry, feeble and without strength, ${ }^{55}$ who are not able ${ }^{56}$ to be saved from ${ }^{57}$ war, but themselves have been led captive.

v. 3 Hear me, ${ }^{58} \mathrm{O}$ house ${ }^{59}$ of Iakob and everyone who is left of Israel, you who are being carried ${ }^{60}$ from the womb and trained since childhood. ${ }^{61}$

v. 4 Until their ${ }^{62}$ old age, I am, and until you grow old, I still $l^{63} \mathrm{am}$; I bear with you; I have made and I as well ${ }^{64}$ will set free; I will take you $^{65}$ up and save you.

v. 5 To whom have you likened me? See, think, ${ }^{66}$ you who are going astray!

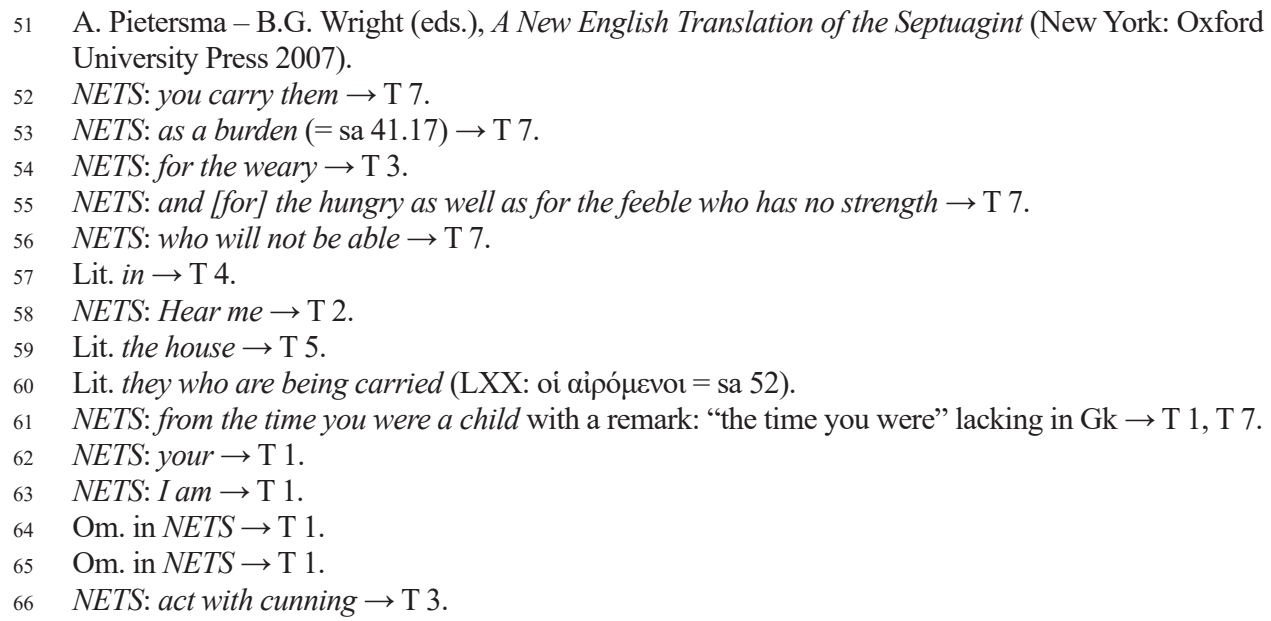


v. 6 Those who contribute gold from their bags ${ }^{67}$ and set silver in a balance on a scale, ${ }^{68}$ and after hiring a goldsmith, they made handiworks ${ }^{69}$ and bowing down ${ }^{70}$ he does obeisance ${ }^{71}$ to $\operatorname{him} !^{72}$

v. 7 They carry them ${ }^{73}$ on their ${ }^{74}$ shoulders and go with them, ${ }^{75}$ and if they set them ${ }^{76}$ up, they stay in their place ${ }^{77}$ they ${ }^{78}$ will not move. And whoever cries out to them ${ }^{79}$ they ${ }^{80}$ will not listen; they ${ }^{81}$ will not save him from evils.

v. 8 Remember these things and groan; repent, you who go astray, ${ }^{82}$ turn in your ${ }^{83}$ heart,

v. 9 and $^{84}$ remember and learn ${ }^{85}$ the former things of old, because I am God, and there is no other god $^{86}$ besides me,

v. 10 declaring the last things first, before they happen, and at once they come to pass,${ }^{87}$ and I said, "My whole plan shall stand, and I will do all the things I desire,"

v. 11 calling a bird from the east and from a far country those concerning whom I have planned. I have spoken and brought him; ${ }^{89} \mathrm{I}$ have created $\mathrm{him}{ }^{90}$ and made him..$^{91}$ I have brought him and I have straightened his way. ${ }^{92}$

v. 12 Hear me, you who have ruined your heart, ${ }^{93}$ you who are far from righteousness:

v. 13 I brought near my righteousness and my truth, ${ }^{94}$ and I will not delay the salvation that comes from me; I have provided salvation to Israel in Sion ${ }^{95}$ for glorying of the Lord. ${ }^{96}$

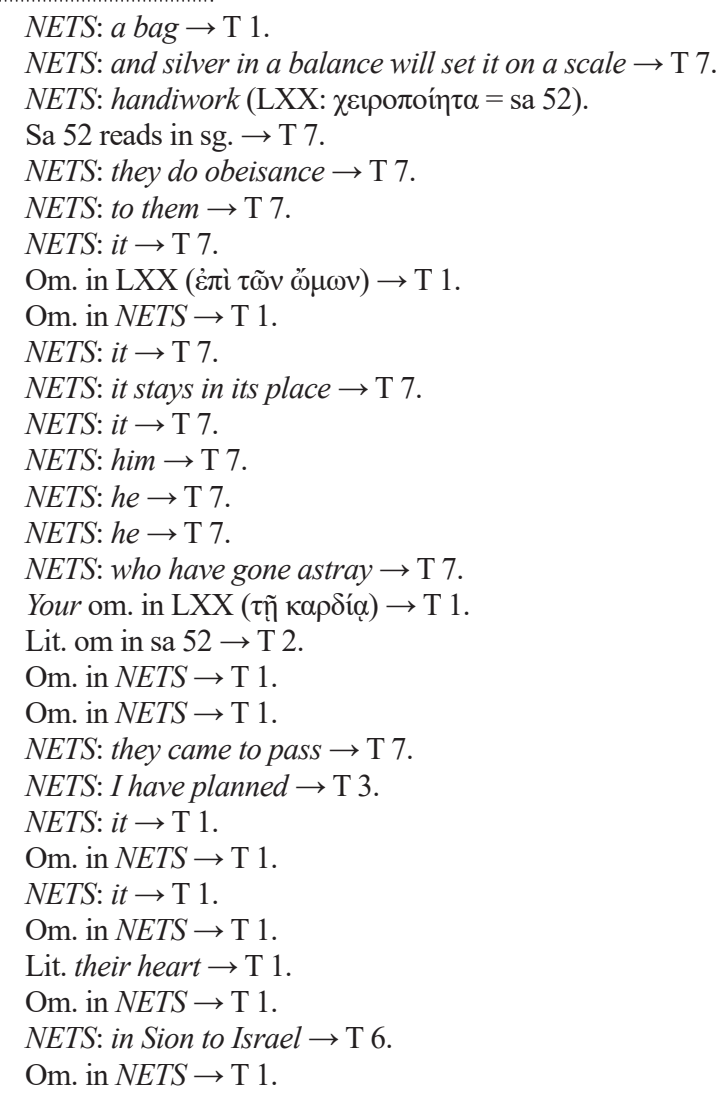




\section{Chapter 47}

v. 1 Come down; sit on the ground, virgin, daughter of Babylon! Sit down Babylon, ${ }^{97}$ the daughter of the Chaldeans. You ${ }^{98}$ shall no longer be called tender and delicate!

v. 2 Take for yourself $f^{99}$ a millstone; grind meals $;{ }^{100}$ uncover your $t h i g h ;{ }^{101}$ expose your ${ }^{102}$ gray hairs; bare your legs; pass through rivers.

v. 3 Your shame shall be uncovered; your reproaches shall appear. ${ }^{103}$ I will take from you what is right; I will no longer deliver you ${ }^{104}$ over to men.

v. 4 He who delivers ${ }^{105}$ you - the Lord Sabaoth is his name, the ${ }^{106}$ Holy One of Israel. ${ }^{107}$

v. 5 Sit distressed; enter the darkness, daughter of the Chaldeans! You shall no more be called the strength of a kingdom.

v. 6 I was provoked at my people; you defiled my heritage. Since $I^{108}$ gave my heritage ${ }^{109}$ into your hand, but you granted $n o^{110}$ mercy to them; you made the yoke of the elder exceedingly heavy. ${ }^{111}$

v. 7 And you said, "I shall be a ruler forever"; you did not consider these things in your heart, nor did you remember last things.

v. 8 But now hear these things, [you $]^{112}$ of whom they say ${ }^{113}$ delicate woman, who sits securely, who says in her heart, "I am, and there is no other one besides me; ${ }^{114}$ I shall not sit as a widow or know bereavement."

v. 9 But now both these things shall come upon you, ${ }^{115}$ in one day; widowhood and loss of children shall come upon you suddenly in your witchcraft $a n d^{116}$ exceedingly in the strength of your enchanters,

v. 10 in the hope of your evil, for you said, "I am and there is no other." Know that the understanding of these things and your fornication ${ }^{117}$ shall be your shame. And you said in your heart, "I am, and there is no other."

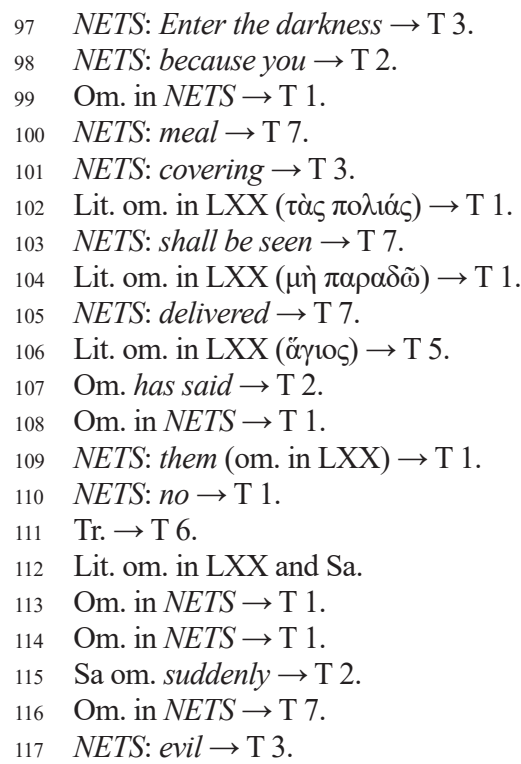


v. 11 But destruction shall come upon you, and you will not realise it; a pit, and you shall fall into it. And wretchedness shall come upon you, and you will not be able to become clean of it, ${ }^{118}$ and wretchedness ${ }^{119}$ shall come upon you suddenly, and you will not realise it. ${ }^{120}$

v. 12 Stand now among your sorcerers ${ }^{121}$ and your ${ }^{122}$ witchcraft, which you learned from your youth; you will not be able to ${ }^{123}$ receive benefit.

v. 13 You have become weary with your counsels; let the astrologers of heaven stand up and save you, those who look at the stars; let them declare to you what is about to come upon you.

v. 14 See, ${ }^{124}$ they all will be burned like brushwood on a fire, and they will not deliver their soul from the flame; since you have coals of fire, $t o^{125}$ sit on them -

v. 15 this way $i t^{126}$ will be a help ${ }^{127}$ to you. You have laboured in your traffic from your ${ }^{128}$ youth; a man has wandered by himself, but for you there will be no salvation.

\section{Chapter 48}

v. 1 Hear these things, $\mathrm{O}$ house of Iakob, who are called by ${ }^{129}$ the name of Israel and who came forth out of Ioudas, who swear by the name of the Lord God of Israel, remembering it, not with truth or with righteousness,

v. 2 and clinging to the name of the ${ }^{130}$ holy city and leaning on the God of Israel; ${ }^{131}$ the Lord Sabaoth is his name.

v. 3 The former things I have moreover declared, and they went out from my mouth and came to be heard; suddenly I did them, and they understood. ${ }^{132}$

v. 4 I know that you are unyielding, and your neck is an iron sinew, and your forehead brass,

v. 5 I declared ${ }^{133}$ to you the things of old; before they came upon you, you heard them; ${ }^{134}$ do not say, "The idols did them for me," 135 and do not say, "The graven and the cast images commanded me." 136

v. 6 You have heard all things, and you yourselves have not known. But I have also informed $y o u,{ }^{137}$ from now on, the new things that shall come to pass, ${ }^{138}$ yet you did not speak.

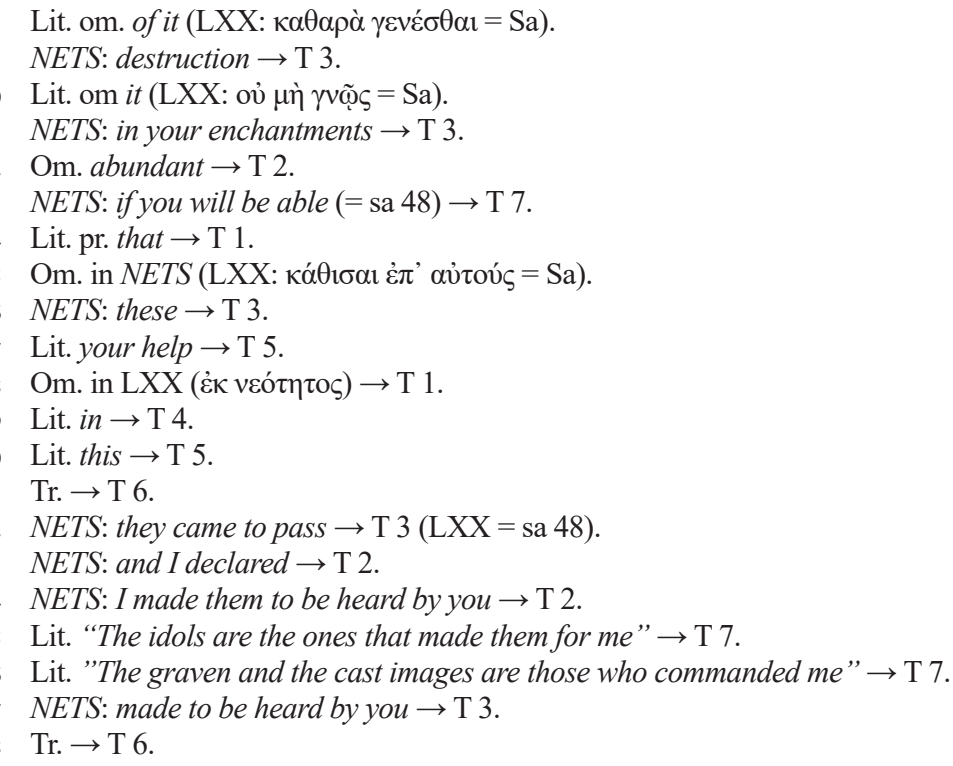


v. 7 They are happening now, not long ago; in former days you did not hear, ${ }^{139}$ do not say, "Yes, I know them."

v. 8 You have neither known them ${ }^{140}$ nor ${ }^{141}$ do you understand them, ${ }^{142}$ nor did you ${ }^{143}$ open your ears from the beginning. For I knew that you would surely reject me, ${ }^{144}$ and that ${ }^{145}$ from the womb you would be called a lawless one.

v. 9 For my name's sake I will show you my wrath; I will bring my glorious deeds upon you so that I may not utterly destroy you.

v. 10 See, I have sold you, not for silver, but I delivered you from the furnace of poverty.

v. 11 For my own sake will I do this to you, because my name is being profaned, and my glory I will not give to another.

v. 12 Hear me, Oh Iakob, and Israel, whom I call: I am the first, and I am forever.

v. 13 And my hand laid the foundation of the earth, and my right hand bolstered heaven; I will call all of ${ }^{46}$ them, and they will stand together.

v. 14 And all of them will be gathered and hear. Who will declare ${ }^{147}$ such $^{148}$ things to them? Because I love you, I have performed your will on Babylon, to do away with the offspring of the Chaldeans.

v. 15 I have spoken; I have called, brought him and made his way prosperous.

v. 16 Draw near to me, and hear these things! From the beginning I have not spoken in secret nor in a dark place of the earth; ${ }^{149}$ when it happened I was there, ${ }^{150}$ and ${ }^{151}$ now the Lord has sent me and his spirit.

v. 17 Thus says ${ }^{152}$ who delivers ${ }^{153}$ you, the Holy Lord $^{154}$ of Israel: I am your God; I have shown you how to find the way in which you should go.

v. 18 And if you had heard my commandments, your peace would have become like a river, and your righteousness like a wave of the sea;

v. 19 your offspring would have become like the sand, and the descendants of your womb like the dust of the earth. Now neither I will destroy you, ${ }^{155}$ nor will your name perish before me.

v. 20 Go out from Babylon, fleeing from the Chaldeans; proclaim a ${ }^{156}$ voice of joy, ${ }^{157}$ and let this be heard; ${ }^{158}$ report it ${ }^{159}$ to the end of earth; say, "The Lord has delivered his slave Iakob!"

Om. of them $\rightarrow \mathrm{T} 2$.

$\mathrm{Om}$. in NETS $\rightarrow \mathrm{T} 1$.

$\mathrm{Om}$. in NETS $\rightarrow \mathrm{T} 1$.

NETS: nor understood $\rightarrow \mathrm{T} 7$.

NETS: $I \rightarrow \mathrm{T} 7$.

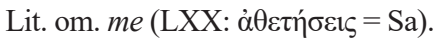

Om. even $\rightarrow$ T 3 .

$\mathrm{Om}$. in NETS $\rightarrow \mathrm{T} 1$.

NETS: has declared $\rightarrow \mathrm{T} 7$.

NETS: these $\rightarrow \mathrm{T} 7$.

$\mathrm{Om}$. in NETS $\rightarrow \mathrm{T} 1$.

$\mathrm{Tr} . \rightarrow \mathrm{T} 6$.

Lit. om. in $\mathrm{Sa} \rightarrow \mathrm{T} 2$.

Om. the Lord $\rightarrow \mathrm{T} 2$.

NETS: delivered $\rightarrow \mathrm{T} 7$.

NETS: One $\rightarrow \mathrm{T} 1$.

NETS: you will be utterly destroyed $\rightarrow \mathrm{T} 7$.

Lit. the voice $\rightarrow \mathrm{T} 5$.

$\mathrm{Tr} . \rightarrow \mathrm{T} 6$.

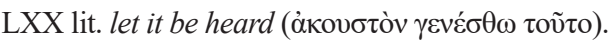

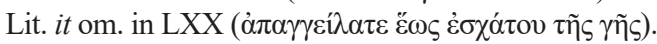


v. 21 Even if they are thirsty in the wilderness, ${ }^{160}$ he will bring forth water for them; ${ }^{161}$ and ${ }^{162}$ he will bring forth water ${ }^{163}$ for them ${ }^{164}$ out of $\mathrm{a}^{165}$ rock; ${ }^{166}$ a rock will be split, and water will flow and the ${ }^{167}$ people will drink. ${ }^{168}$

v. 22 "There is no rejoicing for the impious," says the Lord. ${ }^{169}$

\section{Tables of Language Differences}

The differences between the text of the Septuagint and its Coptic translation will be presented in the following order: additions (Table 1), omissions (Table 2) found in the Coptic text, the use of different vocabulary (Table 3), changes of prepositions (Table 4) and articles (Table 5), ${ }^{170}$ changes in word order (Table 6) ${ }^{171}$ and semantic changes (Table 7). ${ }^{172}$ The last table shows the Greek borrowings appearing in the Coptic text of Isa 41 (Table 8). ${ }^{173}$

The appearance of the note " $>$ Ziegler," means that the phenomenon in question was not observed in Joseph Ziegler's critical apparatus. ${ }^{174}$ First, putting the Greek

160 NETS: Even if they are thirsty, he will lead them through the wilderness $\rightarrow$ philological commentary.

$161 \quad$ NETS: he will lead them $\rightarrow \mathrm{T} 2$.

$162 \mathrm{Om}$. in NETS $\rightarrow \mathrm{T} 1$.

163 Lit. om in sa $52 \rightarrow \mathrm{T} 2$.

$164 \rightarrow$ philological commentary.

165 Lit. the $\rightarrow$ T 5 .

$166 \operatorname{Tr} . \rightarrow \mathrm{T} 6$.

167 NETS: $m y$.

168 NETS: [and my people will drink].

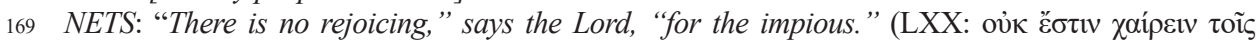

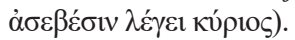

170 Omitting or adding an article does not necessarily result from the translator's intention to interfere in the content. The semantic rules frequently (especially in Coptic) decide about the omission of an article (see e.g., the "zero article" option, limited to a few grammatical situations in: B. Layton, A Coptic Grammar. With Chrestomathy and Glossary. Sahidic Dialect. Second Edition, Revised and Expanded. With an Index of Citations [Wiesbaden: Harrassowitz 2004], § 47). Therefore, it would make no "material" sense to list all the places where the Coptic translation is not faithful to all the articles occurring in the Greek LXX. Table 5 only shows selected examples.

171 The differences in word order do not always have to reflect real changes introduced by the Coptic translator. They can often depend on the syntactic rules according to which, e.g. the direct object usually appears immediately after the verb (cf. Layton, Coptic Grammar, § 182).

172 Here we have included the grammatical and semantic changes (e.g. number, tense, person, gender, etc.). Many of the differences in this category are the introduction of a possessive article or a personal pronoun for the direct object. However, these changes are not always intentional. They often depend on the grammar rules of the language itself. In our study, the Coptic text has been treated very literally. The vast majority of semantic differences have been demonstrated. It is up to the reader to decide which of these changes they consider crucial and which they treat only as an effect of the grammatical rules of the Coptic language.

173 For remarks concerning the tables see Bąk, Isa 41, 76.

174 It is, of course, about a critical edition of the Septuagint: Ziegler, J. (ed.), Septuaginta. Vetus Testamentum Graecum. Auctoritate Societatis Litterarum Gottingensis editum. XIV. Isaias (Göttingen: Vandenhoeck \& Ruprecht 1939). 
word in parentheses with the note: "Sa," means that it appears in Ziegler's critical apparatus. Second, its equivalent has been observed in the Sahidic version of the Coptic language. Unfortunately, Ziegler does not specify which Coptic manuscript he refers to. In some cases, our sa 52 is probably such a manuscript. The note "Sa" in the table does not mean that Ziegler refers only to the Sahidic text. Simultaneously with the note "Sa" he may refer to many Greek manuscripts, the numbers of which are not provided by us, so as not to complicate our tables too much. ${ }^{175}$ Persons with more detailed interests should use Ziegler's critical apparatus. A similar remark applies to the abbreviation "Co," which denotes Coptic manuscripts in general, without distinguishing individual dialects.

\section{Table 1. Additions to the Coptic text}

\begin{tabular}{|c|c|c|}
\hline $46: 3$ & $\begin{array}{l}\dot{\varepsilon} \kappa \pi \alpha 1 \delta \text { íov: since childhood (NETS: } \\
\text { from the time you were a child) }\end{array}$ & $\begin{array}{l}\text { Xï T€YMNTKOYI: since their childhood } \\
\text { (> Ziegler) }\end{array}$ \\
\hline $46: 4$ & 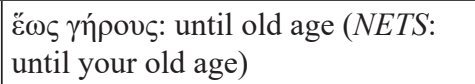 & 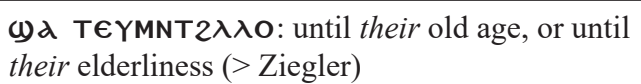 \\
\hline $46: 4$ & 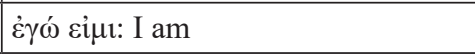 & גNOK ON $\pi €:$ I still am (Ziegler: $+\pi \alpha \lambda \mathrm{sv}$ Co) \\
\hline $46: 4$ & $\dot{\varepsilon} \gamma \hat{\prime} \dot{\alpha} v \eta \dot{\sigma} \sigma$ : I will set free & 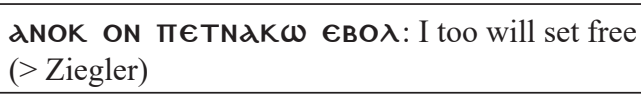 \\
\hline $46: 4$ & 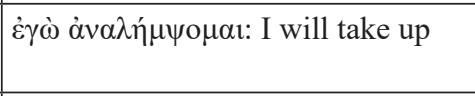 & 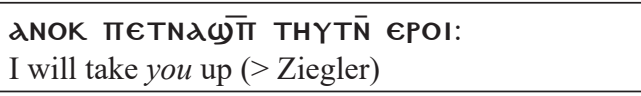 \\
\hline $46: 6$ & $\dot{\varepsilon} \kappa \mu \alpha \rho \sigma ı \pi \pi i ́ o v:$ from a bag & 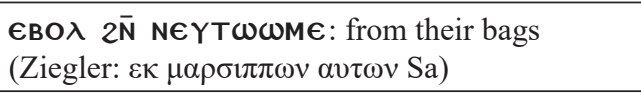 \\
\hline $46: 7$ & 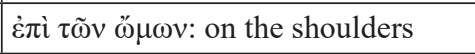 & EXN N€YNA $\overline{2 B}:$ on their shoulders (> Ziegler) \\
\hline $46: 7$ & $\pi \mathrm{o} \rho \varepsilon v \operatorname{lov}_{\tau} \alpha \mathrm{l}$ : they go & 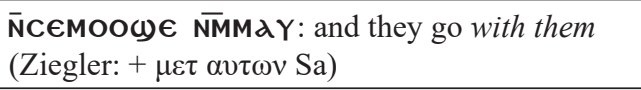 \\
\hline $46: 8$ & 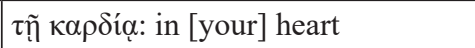 & 2M пєТN2HT: in your heart (> Ziegler) \\
\hline $46: 9$ & $\mu v \eta ́ \sigma \theta \eta \tau \varepsilon:$ remember & $\begin{array}{l}+\overline{\mathbf{N}} T € \mathbf{\epsilon} \overline{\mathbf{N}} \epsilon \mathbf{I M \epsilon}: \text { and learn } \\
(\text { Ziegler: }+\kappa \alpha 1 \gamma \vee \omega \tau \varepsilon \mathrm{Sa})\end{array}$ \\
\hline $46: 9$ & 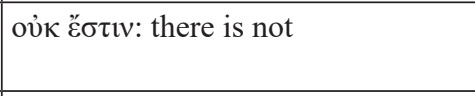 & $\begin{array}{l}\overline{M N} \text { K€NOYT€: there is no other god } \\
\text { (Ziegler: }+\theta \varepsilon \circ \varsigma \text { Sa) }\end{array}$ \\
\hline $46: 11$ & 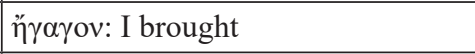 & dî̄T4: I brought him (> Ziegler) \\
\hline $46: 11$ & 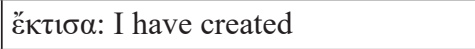 & dïCONT4: I have created him (> Ziegler) \\
\hline $46: 11$ & 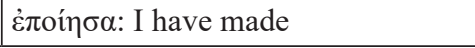 & дїтамїоч: I have made him (> Ziegler) \\
\hline
\end{tabular}

175 For example, in Table 7, in the verse Isa 46:7, there is a note that the Sahidic text, instead of the Greek

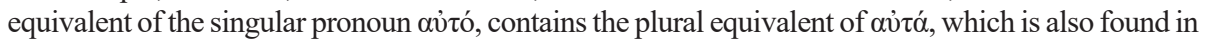
Greek manuscripts such as 26, 239, 407 and 538. In our table, there is only reference to "Sa", without mentioning the Greek manuscripts. 


\begin{tabular}{|c|c|c|}
\hline $46: 11$ & 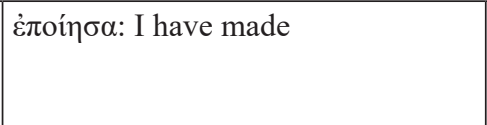 & 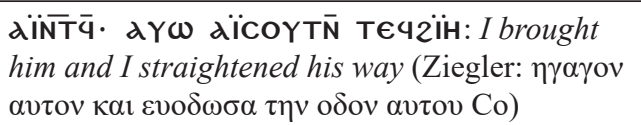 \\
\hline $46: 12$ & 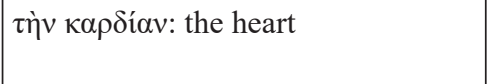 & 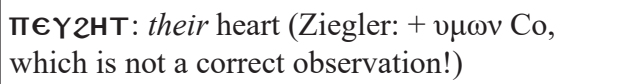 \\
\hline $46: 13$ & 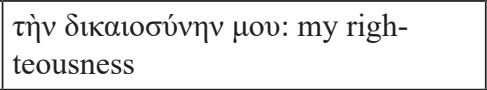 & $\begin{array}{l}+\overline{\mathbf{M N}} \text { TגM€: and my truth } \\
\left(\text { Ziegler: }+\kappa \alpha \iota \tau \eta \nu \alpha \lambda \eta \theta \varepsilon 1 \alpha \nu \mathrm{Co}^{176}\right)\end{array}$ \\
\hline $46: 13$ & 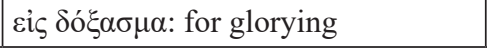 & 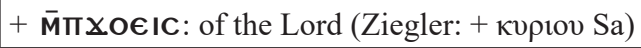 \\
\hline $47: 2$ & 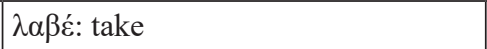 & xï $\mathbf{N} €$ : take for yourself (fem.) (> Ziegler) \\
\hline $47: 2$ & 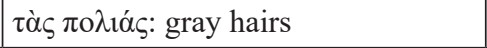 & N̄NoYckï: your gray hairs (Ziegler: + бov Co) \\
\hline $47: 3$ & $\mu \grave{\eta} \pi \alpha \rho \alpha \delta \tilde{\omega}:$ I will not deliver & $\begin{array}{l}\text { NNNATdגT€: I will not deliver you } \\
\text { (Ziegler: }+\sigma \varepsilon \text { Co) }\end{array}$ \\
\hline $47: 6$ & 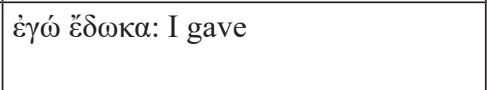 & 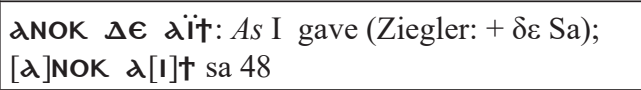 \\
\hline $47: 6$ & $\dot{\varepsilon} \gamma \omega \grave{~ \varepsilon ̌ \delta \omega \kappa \alpha: ~ I ~ g a v e ~}$ & 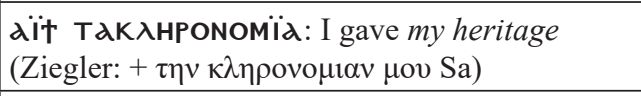 \\
\hline $47: 6$ & 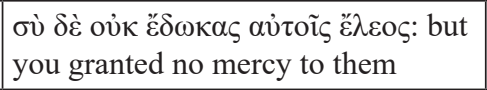 & 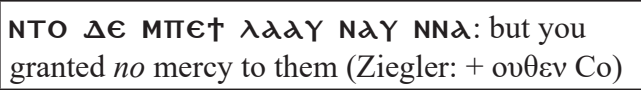 \\
\hline $47: 8$ & 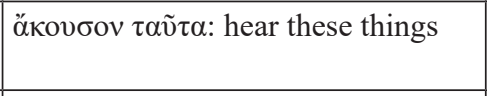 & $\begin{array}{l}\text { + тєтоүмоҮтє єРОс хє: which they talk } \\
\text { about (Ziegler: }+\eta \lambda \varepsilon \gamma о \mu \varepsilon v \eta ~ S a)\end{array}$ \\
\hline $47: 8$ & 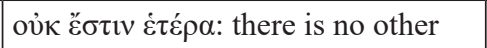 & $+\overline{\mathbf{N}} \overline{\mathrm{B}} \bar{\lambda} \lambda \mathrm{d} \ddot{\mathrm{I}}:$ besides me (>Ziegler) \\
\hline $47: 14$ & íov́: see & pr. $\mathbf{x} \in$ : that (Ziegler: pr. o $\tau \mathrm{Sa}$ ) \\
\hline $47: 15$ & 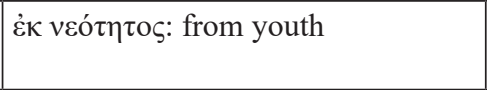 & $\begin{array}{l}\text { XIN TOYMNTKOYI: from your youth } \\
\text { (Ziegler: }+ \text { бov Sa) }\end{array}$ \\
\hline $48: 8$ & 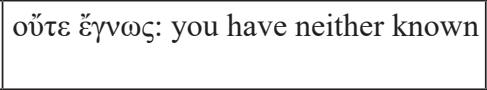 & $\begin{array}{l}\text { OY } \Delta € \text { мпєК€Ім€ €POOY: you have neither } \\
\text { known them (Ziegler: }+\alpha v \tau \alpha \text { Sa) }\end{array}$ \\
\hline $48: 8$ & oü $\varepsilon \varepsilon \dot{\eta} \pi \dot{\sigma} \sigma \tau \omega:$ nor understood & $\begin{array}{l}\text { OY } \Delta € \text { N€KCOOYN dN } \bar{M} M O O Y: \text { nor do you } \\
\text { understand them (Ziegler: }+\alpha v \tau \alpha \mathrm{Sa} \text { ) }\end{array}$ \\
\hline $48: 13$ & $\kappa \alpha \lambda \varepsilon \dot{\sigma} \sigma \omega \alpha v_{\tau o v ́} \varsigma:$ I will call them & $\begin{array}{l}\text { †NגMOYT€ €POOY THPOY: I will call all of } \\
\text { them (Ziegler: }+\pi \alpha v \tau \alpha \varsigma \text { Co) }\end{array}$ \\
\hline $48: 16$ & $\dot{\varepsilon} \lambda \alpha \dot{\lambda} \eta \sigma \alpha:$ I have spoken & 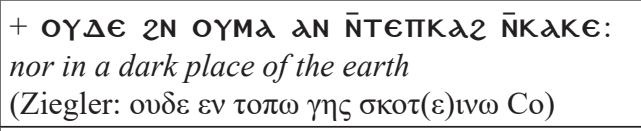 \\
\hline $48: 17$ & o ö $\gamma 10 \varsigma:$ the Holy One & $\begin{array}{l}\text { пхоєї пєтоҮдав: the Holy Lord (Ziegler: } \\
\text { pr. кupios without any references to Coptic) }\end{array}$ \\
\hline $48: 21$ & 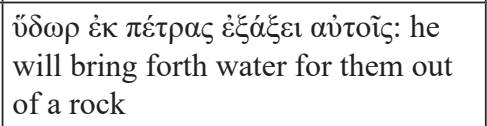 & 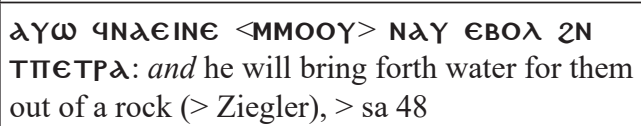 \\
\hline
\end{tabular}

176 The possessive pronoun $\mu \mathrm{ov}$ is missing in Joseph Ziegler's observation. 
Table 2. Omissions in the Coptic text

\begin{tabular}{|c|c|c|}
\hline $46: 3$ & 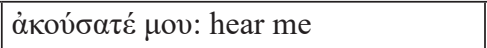 & сштм: hear (Ziegler: om. $\mu$ ov Sa) \\
\hline $46: 9$ & $\kappa \alpha i^{1}$ & lit. om. in sa 52 (Ziegler: om. $\kappa \alpha i^{1} \mathrm{Co}$ ) \\
\hline $47: 1$ & ö $\tau$ : because & om. in sa 52 and sa 48 (Ziegler: om. ö $\tau$ Co) \\
\hline $47: 4$ & $\varepsilon \tilde{\pi} \pi \varepsilon v$ : has said & om. in sa 52 and sa 48 (Ziegler: om. eĩ $\pi \varepsilon v \mathrm{Sa}$ ) \\
\hline $47: 9$ & 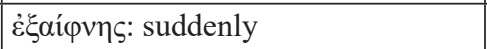 & om. in sa 52 and sa 48 (Ziegler: om. $\grave{\varepsilon} \xi \alpha i ́ \varphi v \eta$ Co) \\
\hline $47: 12$ & $\pi \mathrm{o} \lambda \lambda \tilde{n}:$ abundant & om. in sa 52 and sa 48 (Ziegler: om. $\pi \mathrm{o} \lambda \lambda \tilde{\eta} \mathrm{Sa}$ ) \\
\hline $48: 5$ & $\kappa \alpha i^{1}$ & om. in sa 52 (> Ziegler) \\
\hline $48: 5$ & $\begin{array}{l}\grave{\alpha} \kappa o v \sigma \tau o ́ v \sigma o 1 ~ \varepsilon ̇ \pi o i ́ \eta \sigma \alpha: \text { I made them } \\
\text { to be heard by you }\end{array}$ & 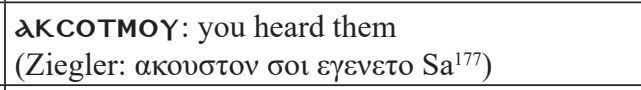 \\
\hline $48: 7$ & 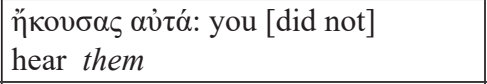 & 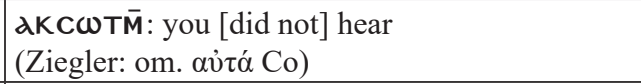 \\
\hline $48: 16$ & $\kappa \alpha i^{2}$ & om. in sa 52 and sa 48 (> Ziegler) \\
\hline $48: 17$ & кúptos & om. in sa 52 and sa 48 (> Ziegler) \\
\hline $48: 21$ & 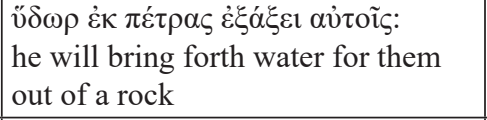 & 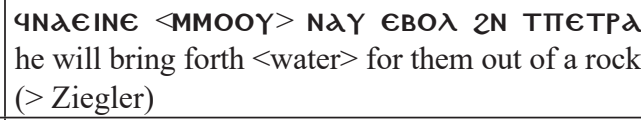 \\
\hline $48: 21$ & {$\left[\kappa \alpha i^{3}\right]$} & lit. om. in sa 52 and sa 48 \\
\hline
\end{tabular}

Table 3. Changes of words

\begin{tabular}{|c|c|c|}
\hline $46: 1$ & 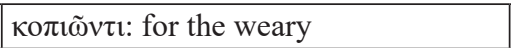 & NïT̄̄: dung (> Ziegler) \\
\hline $46: 5$ & $\begin{array}{l}\tau \varepsilon \chi v \alpha ́ \sigma \alpha \sigma \theta \varepsilon: \text { act with cunning, deal } \\
\text { subtly }\end{array}$ & м€€ү€: think (> Ziegler) \\
\hline $46: 10$ & ö $\sigma \alpha \beta \varepsilon \beta$ ov́ $\lambda \varepsilon v \mu \alpha$ : what I have planned & 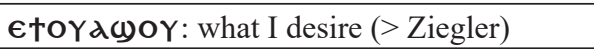 \\
\hline $47: 1$ & 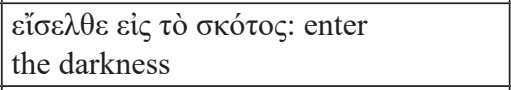 & 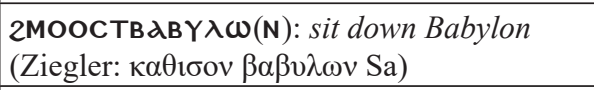 \\
\hline $47: 2$ & 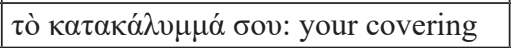 & 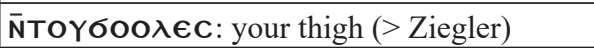 \\
\hline $47: 10$ & 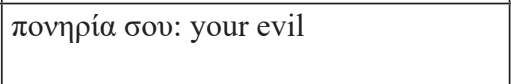 & $\begin{array}{l}\text { ToYmopNId: your fornication } \\
\text { (Ziegler: } \pi \text { o } \nu(\varepsilon) 1 \alpha \text { Co) }\end{array}$ \\
\hline $47: 11$ & $\dot{\alpha} \pi \hat{\omega} \lambda \varepsilon 1 \alpha^{2}:$ destruction & 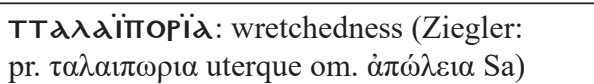 \\
\hline $47: 12$ & $\begin{array}{l}\dot{\varepsilon} v \tau \alpha i \bar{\zeta} \dot{\varepsilon} \pi \alpha o t \delta \alpha i ̃ \zeta ~ \sigma o v: \text { in your en- } \\
\text { chantments }\end{array}$ & $\begin{array}{l}\text { 2€N NOYP€чMOYT€: among your sor- } \\
\text { cerers (> Ziegler), sa 48: } \overline{2 N} \text { NOYMN[T] } \\
\text { P€чMOYT€ = LXX }\end{array}$ \\
\hline $47: 15$ & oṽ $\tau$ or: these & 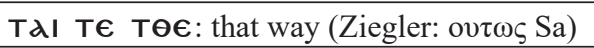 \\
\hline $48: 3$ & 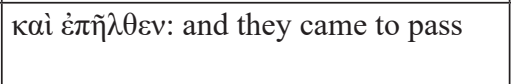 & 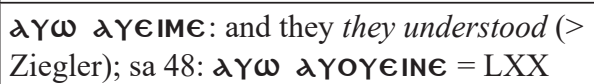 \\
\hline $48: 8$ & 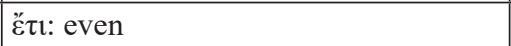 & 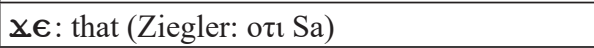 \\
\hline
\end{tabular}

177 See the comment in section 6 . 
Table 4. Changes of prepositions

\begin{tabular}{|c|c|c|}
\hline $46: 2$ & $\dot{\alpha} \pi \mathrm{ò} \pi \mathrm{o} \lambda \dot{\varepsilon} \mu \mathrm{ov}$ : from war & $2 \overline{\mathrm{N}}$ оүполємос: lit. in war (> Ziegler) \\
\hline 48:1 & $\tau \tilde{\omega}$ ỏvó $\mu \alpha \tau \imath$ : by the name & $\overline{2 M}$ ПтдN: lit. in the name (> Ziegler) \\
\hline
\end{tabular}

Table 5. Changes of articles

\begin{tabular}{|c|c|c|}
\hline $46: 3$ & oĩkos: house & пніі: the house (Ziegler: pr. о Co) \\
\hline $47: 4$ & örios: holy one & пєтоүдав: the holy one (Ziegler: pr. о Co) \\
\hline $47: 15$ & $\beta$ ßо́ $\theta \varepsilon 1 \alpha:$ a help & тоүвонөїд: lit. your help (Ziegler: pr. $\eta \mathrm{Sa}$ ) \\
\hline $48: 2$ & $\tau \tilde{\eta} \varsigma \pi$ ó $\lambda \varepsilon \omega \varsigma:$ of the city & NT€Ітолї: of this city (> Ziegler) \\
\hline $48: 20$ & $\varphi \omega v \eta ́ v:$ a voice & м̄тє2РОoY: the voice (> Ziegler) \\
\hline $48: 21$ & $\dot{\varepsilon} \kappa \pi \dot{\varepsilon} \tau \rho \alpha \varsigma:$ out of a rock & $\begin{array}{l}\text { ЄBO } \lambda \text { 2N TாЄTPA: out of the rock } \\
\text { (> Ziegler) }\end{array}$ \\
\hline
\end{tabular}

Table 6. Changes in word order

\begin{tabular}{|c|c|c|}
\hline $46: 13$ & 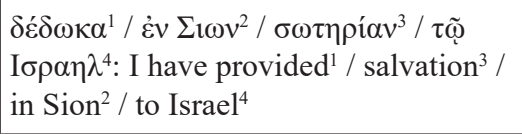 & 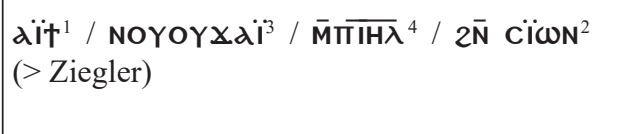 \\
\hline $47: 6$ & 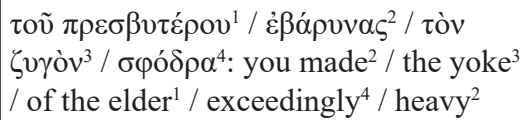 & 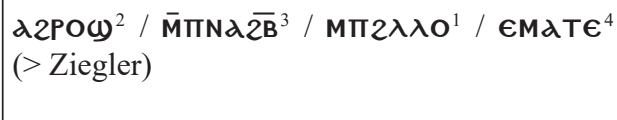 \\
\hline $48: 2$ & 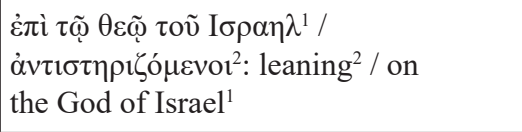 & 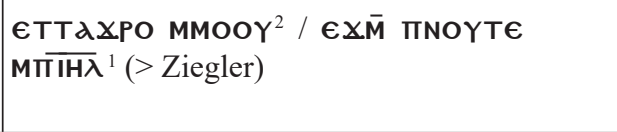 \\
\hline $48: 6$ & 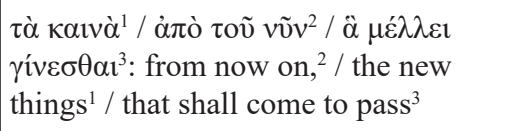 & 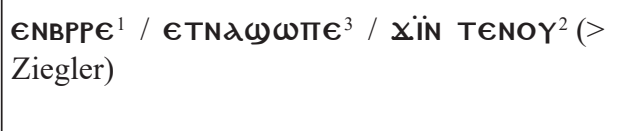 \\
\hline $48: 16$ & 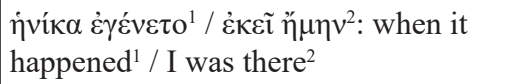 & 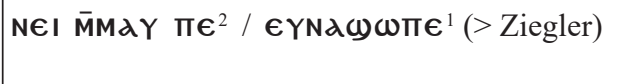 \\
\hline $48: 20$ & 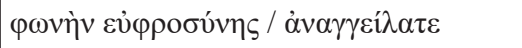 & 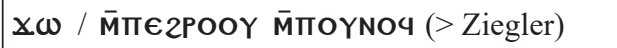 \\
\hline $48: 21$ & 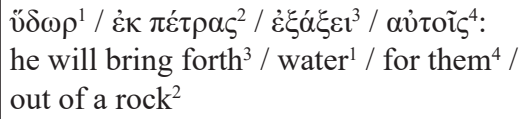 & 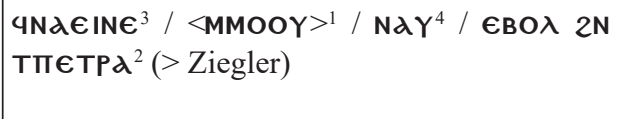 \\
\hline
\end{tabular}


Table 7. Semantic changes

\begin{tabular}{|c|c|c|}
\hline $46: 1$ & 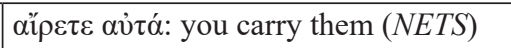 & чїтоY: carry (iptv.) them! (> Ziegler) \\
\hline $46: 1$ & 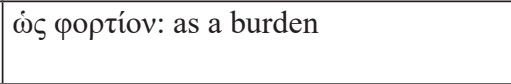 & 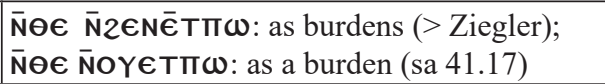 \\
\hline $46: 2$ & 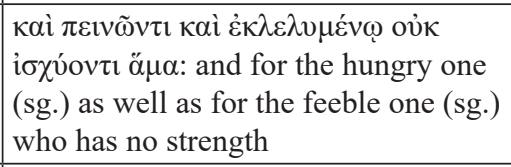 & 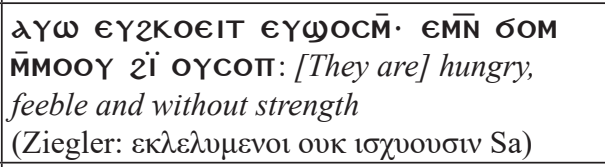 \\
\hline $46: 2$ & 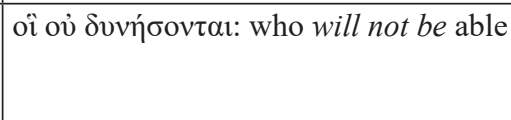 & 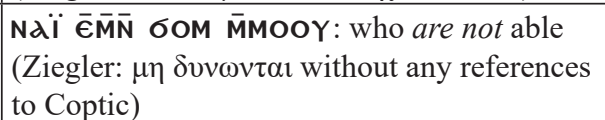 \\
\hline $46: 3$ & $\begin{array}{l}\dot{\varepsilon} \kappa \pi \alpha 1 \delta \text { íov:since childhood (NETS: } \\
\text { from the time you were a child) }\end{array}$ & $\begin{array}{l}\text { Хï T€YMnTKOYı: from their childhood } \\
\text { (> Ziegler) }\end{array}$ \\
\hline $46: 6$ & 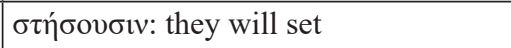 & 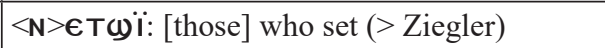 \\
\hline $46: 6$ & 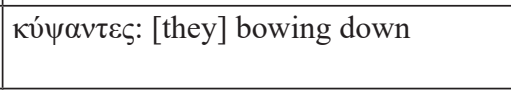 & 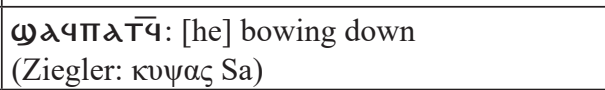 \\
\hline $46: 6$ & $\pi \rho \circ \sigma \kappa v v o \tilde{\sigma} \sigma \mathrm{v}:$ they do obeisance & 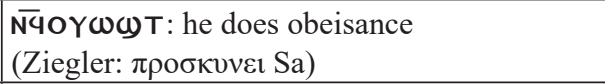 \\
\hline $46: 6$ & 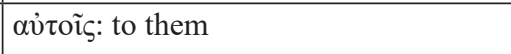 & Nג4: to him (Ziegler: $\alpha$ vo Co) \\
\hline $46: 7$ & 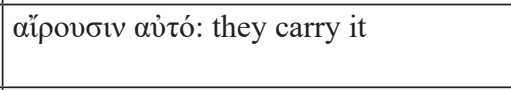 & $\begin{array}{l}\text { WdYчïToY: they carry them (Ziegler: } \\
\alpha v \tau \alpha \mathrm{Sa})\end{array}$ \\
\hline $46: 7$ & 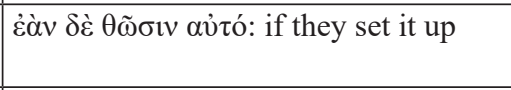 & 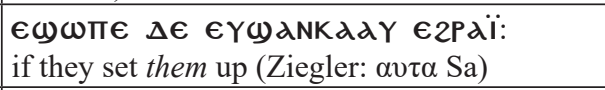 \\
\hline $46: 7$ & 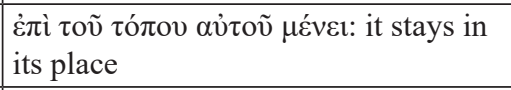 & 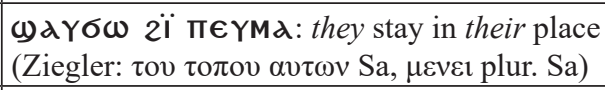 \\
\hline $46: 7$ & 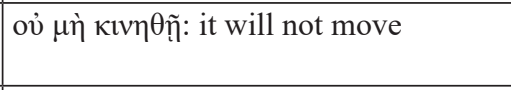 & 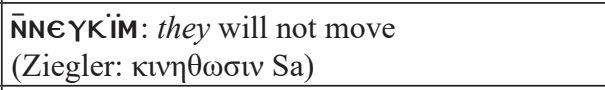 \\
\hline $46: 7$ & $\pi \rho o ̀ \varsigma \alpha$ $\tau$ óv: to him & €POOY: to them (Ziegler: $\alpha v \tau \alpha \mathrm{Sa}$ ) \\
\hline $46: 7$ & 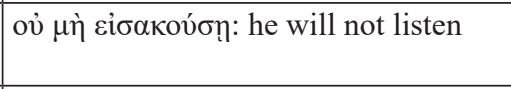 & 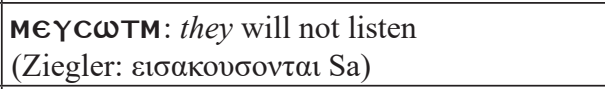 \\
\hline $46: 7$ & 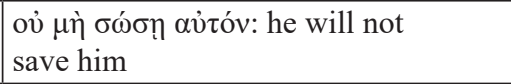 & $\begin{array}{l}\text { N̄N€YNd2M€4: they will not save him } \\
\text { (Ziegler: } \sigma \omega \sigma \omega \sigma v \mathrm{Sa})\end{array}$ \\
\hline $46: 8$ & $\begin{array}{l}\text { oi } \pi \varepsilon \pi \lambda \alpha \nu \eta \mu \varepsilon ́ v o t:[y o u] \text { who have } \\
\text { gone astray }\end{array}$ & 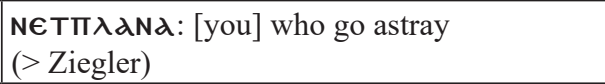 \\
\hline $46: 10$ & $\sigma u v \varepsilon \tau \varepsilon \lambda \varepsilon \dot{\varepsilon} \sigma \eta \eta$ they came to pass & $\begin{array}{l}€ \mathrm{\epsilon} \times \boldsymbol{X K} \in \mathbf{\epsilon B O} \lambda: \text { [they] come to pass (Ziegler: } \\
\sigma v v \tau \varepsilon \lambda \varepsilon \sigma \theta \eta \text { without any references to Coptic) }\end{array}$ \\
\hline $47: 2$ & 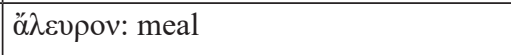 & 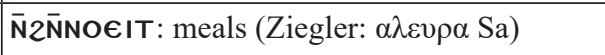 \\
\hline $47: 3$ & 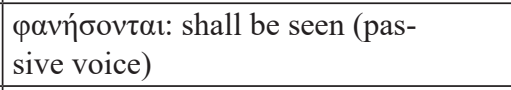 & 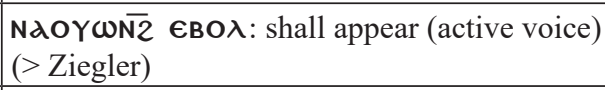 \\
\hline $47: 4$ & ó $\rho v \sigma \alpha ́ \mu \varepsilon v o ́ \varsigma \sigma \varepsilon:$ who delivered you & 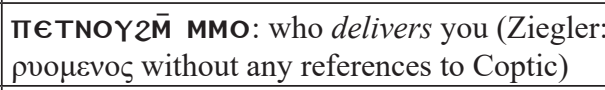 \\
\hline 47:9 & $\dot{\varepsilon} v \tau \tilde{n}$ i $\sigma \chi v ́ t:$ in the strength & 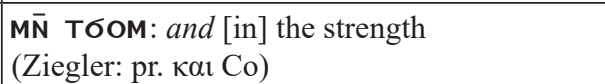 \\
\hline
\end{tabular}




\begin{tabular}{|c|c|c|}
\hline $47: 12$ & $\begin{array}{l}\varepsilon i ̉ ~ \delta v v \eta ́ \sigma \eta ~ \omega ̉ \varphi \varepsilon \lambda \eta \theta \tilde{\eta} v \alpha \text { : if you will } \\
\text { be able }\end{array}$ & 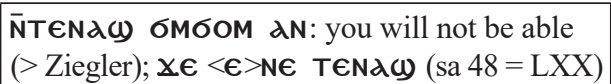 \\
\hline $48: 5$ & 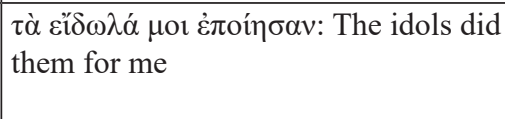 & 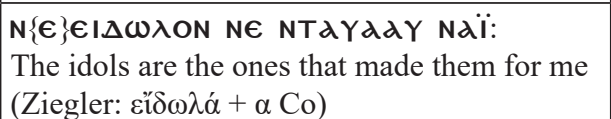 \\
\hline $48: 5$ & 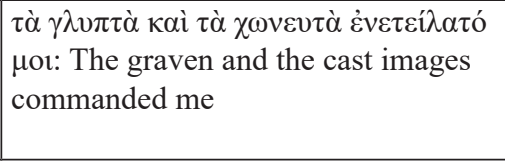 & 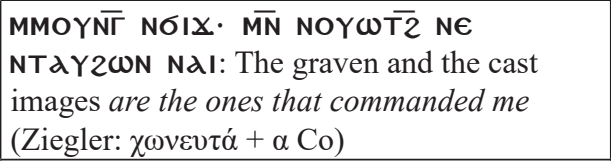 \\
\hline $48: 6$ & 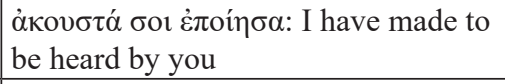 & дїтдмоK: I have informed you (> Ziegler) \\
\hline $48: 8$ & 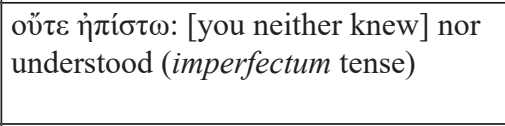 & 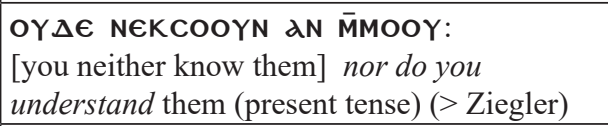 \\
\hline $48: 8$ & 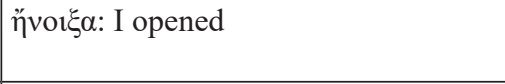 & 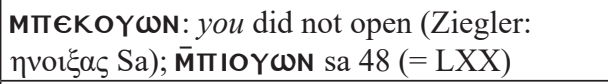 \\
\hline $48: 14$ & $\dot{\alpha} v \eta ́ \gamma \gamma \varepsilon 1 \lambda \varepsilon v$ : [who] has declared & $\begin{array}{l}\text { NIM пєTNגХW: who will declare (Ziegler: } \\
\alpha v \alpha \gamma \gamma \varepsilon \lambda \varepsilon l \text { without any references to Coptic) }\end{array}$ \\
\hline $48: 14$ & $\tau \alpha \tilde{v} \tau \alpha:$ these things & 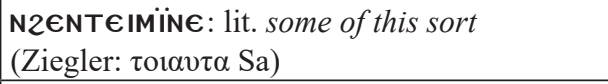 \\
\hline $48: 17$ & 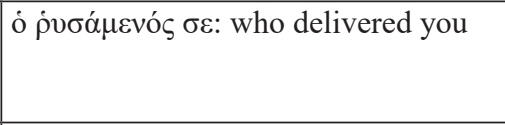 & 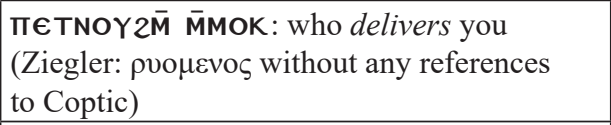 \\
\hline $48: 19$ & 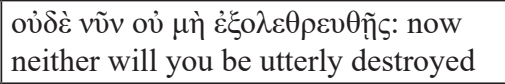 & $\begin{array}{l}\text { T€NOY ON NNגBOTK } € \text { ВOA: now neither } \\
\text { will I destroy you (> Ziegler) }\end{array}$ \\
\hline $48: 21$ & 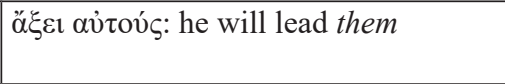 & 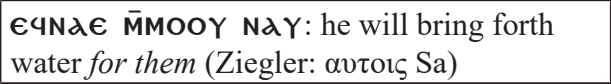 \\
\hline $48: 21$ & 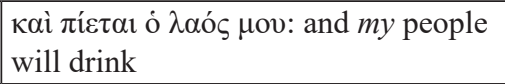 & 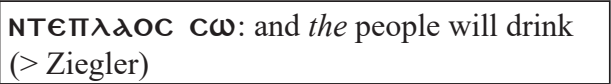 \\
\hline
\end{tabular}

Table 8. Greek words in the Coptic text

\begin{tabular}{|c|c|c|}
\hline $48: 8(2 x)$ & $\grave{\alpha} \theta \varepsilon \tau \varepsilon \dot{\varepsilon} \omega$ & дөдїтєї \\
\hline $46: 2$ & 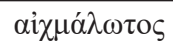 & 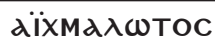 \\
\hline $48: 6$ & $\dot{\alpha} \lambda \lambda \dot{\alpha}$ & $d \lambda \lambda d$ \\
\hline $46: 4$ & 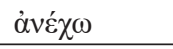 & dNEXE \\
\hline $48: 8$ & övouos & ANOMOC \\
\hline $47: 7$ & $\alpha \rho^{\prime} \alpha \omega \nu$ & APXWN \\
\hline $48: 22$ & 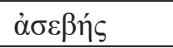 & dC€BHC \\
\hline $47: 1(2 x) ; 48: 14.20$ & 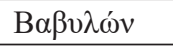 & BdBY $\lambda \omega N$ \\
\hline $46: 1$ & $\mathrm{~B} \eta \lambda$ & $\mathrm{BH} \lambda$ \\
\hline $47: 15$ & 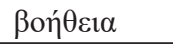 & вонөїд \\
\hline $47: 10 ; 48: 8$ & $\gamma \alpha ́ \rho$ & $\Gamma d P$ \\
\hline
\end{tabular}




\begin{tabular}{|c|c|c|}
\hline $46: 1$ & $\Delta \alpha \gamma \omega \nu$ & TגГ山N \\
\hline $46: 2.7 ; 47: 6(2 x) .9 .15 ; 48: 10$ & $\delta \varepsilon \dot{\varepsilon}$ & $\Delta \epsilon$ \\
\hline $46: 12.13 ; 48: 1.18$ & $\delta 1 \kappa \alpha 10 \sigma u ́ v \eta$ & $\triangle \ddot{I K}$ גIOCYNH \\
\hline $48: 5$ & $\varepsilon \Uparrow \delta \omega \lambda \mathrm{ov}$ & $\epsilon I \Delta \omega \lambda O N$ \\
\hline $48: 18$ & 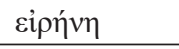 & EIPHNH \\
\hline $47: 10$ & $\dot{\varepsilon} \lambda \pi \dot{i} \zeta$ & $\theta \epsilon \lambda \pi \ddot{i c}$ \\
\hline $48: 18$ & $\dot{\varepsilon} v \tau \mathrm{O} \lambda \dot{n}$ & $€ N T O \lambda H$ \\
\hline 48:18 & $\theta \alpha \dot{\lambda} \alpha \sigma \sigma \alpha$ & $\theta d \lambda d C C \lambda$ \\
\hline $46: 1$ & Onpíov & OHPION \\
\hline $46: 3 ; 48: 1.12 .20$ & $\operatorname{I} \alpha \kappa \omega \beta$ & $I A K \omega B$ \\
\hline $48: 1$ & Iov $\delta \alpha$ & IOY $\Delta d$ \\
\hline $46: 3.13 ; 47: 4 ; 48: 1(2 x) \cdot 2 \cdot 12 \cdot 17$ & I $\sigma \rho \alpha \eta \lambda$ & $\overline{\Pi \mathrm{IH} \lambda}$ \\
\hline $47: 15$ & 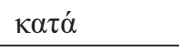 & KdTd \\
\hline $47: 6(2 x)$ & $\kappa \lambda \eta \rho о \nu о \mu i ́ \alpha$ & K入HPONOMÏд \\
\hline $47: 6 ; 48: 21$ & $\lambda \alpha o ́ \varsigma$ & $\lambda d O c$ \\
\hline $47: 15$ & $\mu \varepsilon \tau \alpha \beta o \lambda \eta ́$ & MNT АBO $\lambda H$ \\
\hline $46: 8$ & $\mu \varepsilon \tau \alpha \nu \circ \varepsilon ́ \omega$ & METANOÏ \\
\hline $47: 7$ & voÉ $\omega$ & NOI \\
\hline $47: 8$ & 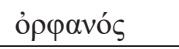 & OPФАNOC \\
\hline $47: 7 ; 48: 1.8(3 x) \cdot 16 \cdot 19$ & 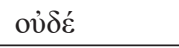 & OY $\Delta \epsilon$ \\
\hline $47: 1$ & $\pi \alpha \rho \theta \dot{v} v o \varsigma$ & IגPӨ€NOC \\
\hline $48: 21(2 x)$ & $\pi \varepsilon ́ \tau \rho \alpha$ & пєТРд \\
\hline $46: 5.8 ; 47: 15$ & $\pi \lambda \alpha v \alpha ́ \omega$ & $\Pi \lambda \lambda d \alpha$ \\
\hline $48: 16$ & $\pi v \varepsilon \tilde{u} \mu \alpha$ & $\overline{\Pi N \lambda}$ \\
\hline $46: 2$ & $\pi \delta ́ \lambda \varepsilon \mu \sigma_{\varsigma}$ & полємос \\
\hline $48: 2$ & $\pi$ ó $\lambda 1 \zeta$ & полїс \\
\hline $47: 10$ & $\pi$ ovๆpía & пONHPIid \\
\hline $47: 10$ & $\pi$ opveía & TOPNId \\
\hline $47: 4 ; 48: 2$ & $\sigma \alpha \beta \alpha \omega \theta$ & 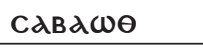 \\
\hline $46: 13$ & $\Sigma 1 \omega v$ & CïWN \\
\hline 48:14.19 & $\sigma \pi \varepsilon \dot{\varepsilon} \rho \mu \alpha$ & спєРмд \\
\hline $47: 11(2 x)$ & $\tau \alpha \lambda \alpha \imath \pi \omega \rho i ́ \alpha$ & 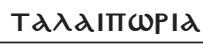 \\
\hline $47: 1.5 ; 48: 14.20$ & $\mathrm{X} \alpha \lambda \delta \alpha i{ }^{\prime} \varsigma \varsigma$ & $x d \lambda \Delta d \ddot{i o c}$ \\
\hline $47: 8.9$ & $\chi \eta ́ \rho \alpha$ & XHPd \\
\hline $47: 14$ & $\psi v \chi \eta ́$ & $\Psi Y X H$ \\
\hline
\end{tabular}




\section{An Analysis of Selected Philological Questions Found in Isa 46-48}

\section{Isa 46:1}

The Greek verb aipe $\rho \varepsilon$ can be interpreted as both the 2 pl. indicative ("you carry") and imperative ("Carry!"). NETS translators prefer the first option. The Coptic translator, on the other hand, by using the form ciiToY, which is not preceded by any subject, opts for the imperative ("carry them!"). If he had translated the

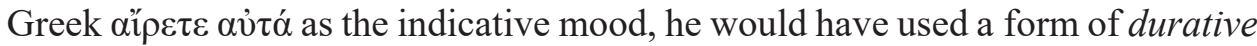

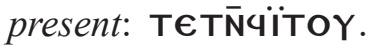

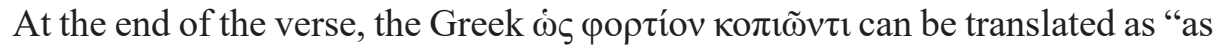
a burden for the weary." In the Coptic manuscript sa 52 we encounter the transla-

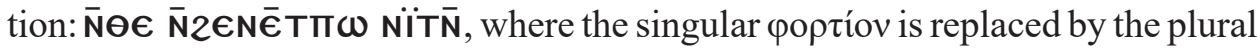

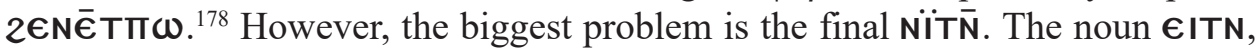
sometimes spelled ïT̄, means: "ground," "earth," "dust," "rubbish."179 The letter $\mathbf{N}$ - preceding it should then be interpreted as the so-called $\overline{\mathbf{N}}$-attributive. ${ }^{180}$

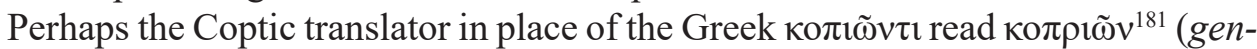
itivus pluralis form from кó $\pi \rho 10 v)$, meaning precisely "dirt," "filth," "dung." 182 The use of the Coptic NITN (ITTे preceded by the plural N-) as a translation

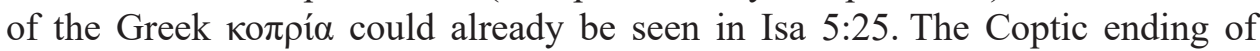
the verse $\overline{\mathbf{N}} \boldsymbol{\Theta} \overline{\mathbf{N}} 2 € \mathbf{\epsilon} \bar{\epsilon} T \Pi \omega$ NiTT could then be translated: like loads of dung.

\section{Isa 46:6}

The final part of the verse in the Coptic translation is difficult to understand. The translator first describes the activities of those who create their own idols in the plural form. Later, when their work is done, the scribe shifts to the singular form: "he bows down and worships him." It is difficult to determine who the $3 \mathrm{sg}$. masculine pronoun refers to. Perhaps the author is referring to a goldsmith (Copt. 2 XYNOYB), who makes obeisance to the idol he has created. The plural form reappears at the beginning of the next verse.

\section{Isa 46:12}

In the Coptic translation of the noun $\tau \grave{\eta} v \kappa \alpha \rho \delta$ íav, a singular masculine possessive article was added, which referred to the third-person plural pronoun: $\Pi \epsilon \boldsymbol{Y}$.

\footnotetext{
178 Manuscript sa 41.17 contains an LXX-compatible singular form: oY€Tாஸ.

179 Crum, Coptic Dictionary, 87b.

180 See Layton, Coptic Grammar, § 99.

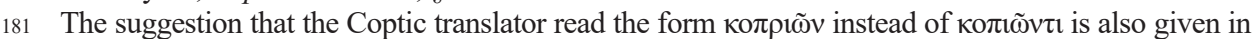
Crum (Coptic Dictionary, 87b).

182 Lust, Greek-English Lexicon, 350b.
} 
In this way the form пє Ү2HT ("their heart") was created in the Coptic text. Ziegler's critical apparatus suggests that there is an equivalent of the Greek possessive pronoun $v \mu \omega v$ ("your") in the Coptic text, which corresponds neither to the manuscript sa 52 nor to sa 41.17! Only in the Syrian text ("Syl”) does Ziegler notice the equivalent of the pronoun $\alpha v \tau \omega v$ ("their").

\section{Isa 47:2}

Much greater linguistic richness can be observed in the LXX verse than in the

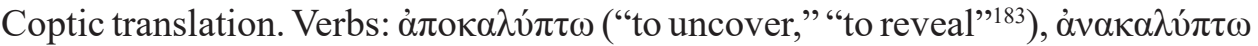
("to uncover," "to discover," "to disclose"184), àv $\alpha \sigma u ́ \rho \omega$ ("to expose," "to lay bare," "to uncover" 185 ) were translated by a Coptic translator with the same word $\sigma \omega \lambda \Pi \epsilon$ the variety of verbal forms have been preserved in the English translation of this verse.

\section{Isa 47:4}

The manuscript sa 48 contains the text пє TNOY $2 \overline{\mathbf{M}}$ MMOK, which suggests that the $2 \mathrm{sg}$. pronoun is masculine. The context, however, points to a female person to whom the subject turns in the first verse of this chapter. It is TחגPø€NOC

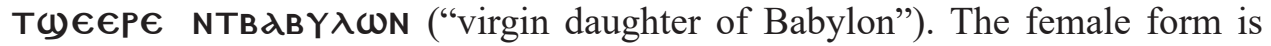
also illustrated by such forms from verse 3 as поүต їா ("your shame"), or NOYNOбN€б ("your reproaches"), containing $2 \mathrm{sg}$. feminine possessive articles: поY- and NOY-. The reading of the manuscript sa 52: пєTNOY2M ммо is therefore more grammatically correct than the manuscript sa 48. Sa 52 indicates a 2 pl. direct object of precisely feminine gender $\left(\mathbf{M M O}^{187}\right)$.

\section{Isa 47:6}

In Ziegler's critical apparatus we find a commentary stating that the Coptic texts

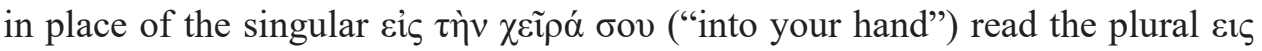
$\tau \alpha \varsigma \chi \varepsilon i \rho \alpha \varsigma$ бov ("into your hands"). Ziegler's remark is inconsistent with either sa 52 or sa 48 manuscript. They both include the reading of $€$ TоYбIx, which is

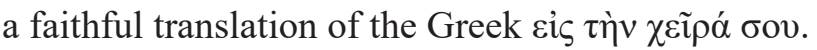

In the Coptic expression di† TגK入HPONOMi̇ ("I gave my heritage"), the manuscript sa 48 adds $\mathbf{N}-$, which denotes a direct object and reads

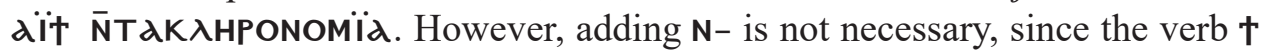

\footnotetext{
183 Lust, Greek-English Lexicon, 68.

184 Lust, Greek-English Lexicon, 38.

185 Lust, Greek-English Lexicon, 44.

186 Crum, Coptic Dictionary, 812a.

187 See Layton, Coptic Grammar, § 85.
} 
can be a prenominal form ${ }^{188}$ that can be linked directly to the direct object and does not require the letter $\mathbf{N}$-. Both readings: sa 52 and sa 48 are therefore correct.

\section{Isa 47:9}

In the manuscript sa 52 , we find the expression $2 \in \mathbf{N}$ oY $\omega$ CN $€$ ("suddenly") which corresponds directly to the Greek $\dot{\varepsilon} \xi \alpha i ́ p \vee \eta \varsigma$ ("suddenly"189). The manuscript sa 48 reads $\overline{2 N}$ O $[\mathrm{Y}] \boldsymbol{\omega} \mathbf{N} \epsilon$ here, which is difficult to interpret. That is because the noun $\boldsymbol{\omega N} \Theta$ means either "net" 190 or "garden." 191 The expression $\overline{2 N}$ o[Y] $\boldsymbol{\omega N} \Theta$ therefore means "in the net" or "in the garden" and in no way corresponds to the Greek $\dot{\varepsilon} \xi \alpha i \varphi v \eta$. The exact same situation happens again in verse 11 . The reading of sa 48 thus remains the hallmark of this manuscript, reading $\overline{2 N}$ oYwNE instead of $\overline{2 N}$ OY $\omega \mathrm{CN} \epsilon$. The manuscript sa 52 contains a correct version raising no doubts.

\section{Isa 47:15}

The Coptic expression KdTd POY ("by himself") consists of the Greek preposition $\mathrm{K} \boldsymbol{\mathrm { A } T \mathrm { d }}$ and the pre-suffixal form $\mathrm{P} \boldsymbol{\omega}=$, derived from the noun $\mathrm{PO}$ ("mouth"192), to which the 3sg. masculine suffix 4 was attached. The correct notation should, however, take the form of KdTd PW4. Both our manuscript sa 52 and sa 48 include reading with the shortened omicron vowel PO4. Crum's dictionary does not take into account the pre-suffixal form *PO=. However, we find it in the Polish-language Coptic dictionary, which was developed by Wincenty Myszor. It even includes the whole expression $\mathrm{K} \boldsymbol{\mathrm { T }} \mathrm{T} \boldsymbol{d}-\mathbf{P O}=.{ }^{193} \mathrm{We}$, therefore, adopt the expression KdTd PO4 as an alternative to KdTd PW4.

\section{Isa 48:1}

In the manuscript sa 48 , we find the form $\mathbf{N} \boldsymbol{\epsilon} \mathbf{T}[\boldsymbol{\epsilon} \mathbf{I}] \mathbf{P} \boldsymbol{\epsilon}$, in which the relative structure $\boldsymbol{\epsilon}[\boldsymbol{\epsilon} \mathbf{I}] \mathbf{P} \boldsymbol{\epsilon}$ has been nominalised by adding the plural article $\overline{\mathbf{N}}-$. Thus, the structure $\mathbf{N} \in \mathbf{T}[\boldsymbol{\epsilon} \mathbf{I}] \mathrm{P} \boldsymbol{E}$ literally means "those who do" 194 and is a continuation of forms such as NENTAYTd2MOY ("who are called") and N€TWPK ("who swear").

The reading of the manuscript sa 52 is somewhat less clear here. The lack of an article means that the relative form $\boldsymbol{\epsilon} \mathbf{T} \boldsymbol{I P} \boldsymbol{\epsilon}$ could refer to the noun preceding

188 Cf. Crum, Coptic Dictionary, 392a.

189 Lust, Greek-English Lexicon, 209b.

190 Crum, Coptic Dictionary, 571b.

191 Crum, Coptic Dictionary, 572a.

192 Crum, Coptic Dictionary, 288a.

193 W. Myszor, Podręczny stownik języka koptyjskiego (Warszawa: Wydawnictwo Akademickie Dialog 1996) 54a.

194 The entire Coptic expression N€T€IP€ мп€чм€€Y€ is translated by us as "those who remember" (see Crum, Coptic Dictionary, 84a). 
it TNOYT€ $\overline{\mathrm{M}} \overline{\mathrm{TIH} \lambda}$ ("God of Israel"). "Those who do" could then be translated as "the God of Israel who does." The text of sa 52 is therefore ambiguous.

When comparing the manuscript sa 52 to the manuscript sa 48, it is difficult to determine which form - $\boldsymbol{\epsilon} \mathbf{T} \boldsymbol{I P} \boldsymbol{\epsilon}$ or $\mathbf{N} \boldsymbol{\epsilon} \mathbf{T}[\boldsymbol{\epsilon} \mathbf{I}] \mathbf{P} \boldsymbol{\epsilon}$ - is more correct. On the one hand, the text becomes clearer in sa 48. On the other, the reading of sa 52 is more faithful to the Greek text, which contains a participle $\mu \mu v \eta \eta \sigma \kappa o ́ \mu \varepsilon v o r$ not preceded by an article. In our study, we leave the reading $\boldsymbol{\epsilon} \boldsymbol{\top} \boldsymbol{\epsilon} \mathbf{P} \boldsymbol{\epsilon}$ as the preferred one (no "!!" sign next to $\mathbf{N} \boldsymbol{\epsilon}[\boldsymbol{\epsilon} \mathbf{I}] \mathbf{P} \boldsymbol{\epsilon}$ ). Although it is more difficult (less unambiguous), it is nevertheless more faithful to the reading of the Septuagint.

\section{Isa 48:3}

The Coptic manuscript sa 52 deviates entirely from the Greek verb $\dot{\varepsilon} \pi \tilde{\eta} \lambda \theta \varepsilon v$ ("they came to pass"). In our manuscript, the form $\mathbf{\alpha}\} \in \mathbf{I M \epsilon}$ appears, which means literally "they understood." The DECOT study ${ }^{195}$ suggests that $\mathbf{a} Y \in \mathbf{I N} €,{ }^{196}$ should be the correct reading, although this claim is difficult to agree with. The verb $€ \mathbf{I N} €$ means "to bring," "to bear." 197 Therefore, it does not belong in any way to the semantic scope of the Greek verb غ̇лé $\chi \chi \mu \alpha$.

The most appropriate form is contained by the manuscript sa 48, in which we encounter dYOY€IN€. The verb oY $€ \mathbf{I N} €$ means "to pass by" 198 and is the exact

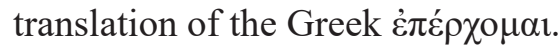

\section{Isa 48:5}

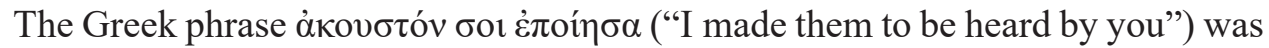
translated in Sahidic manuscripts in a simplified way, as aKcoTMOY ("you heard about them"). In Ziegler's critical apparatus, ${ }^{199}$ we find information suggesting

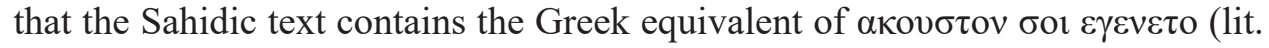
"it became audible to you"). However, neither in the manuscript sa 52 manuscript, nor sa 48 , nor sa $108^{\mathrm{L}}$ do we find an equivalent of the Greek $\gamma^{\prime}$ vo $\mu \alpha$. The Coptic text is a translation of the Greek tion does not refer accurately to the Coptic aксотмоY.

It is noted in Ziegler's critical apparatus that the Coptic text reads the Greek

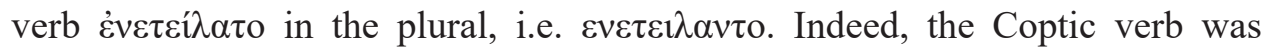
grammatically notated in the plural as dY2WN ("they commanded"). Howev-

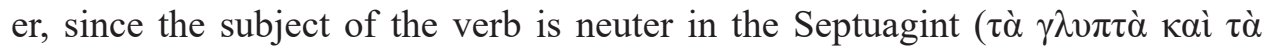
$\chi \omega v \varepsilon v \tau \alpha$ ) , the Greek verb can be both singular and plural. The Greek language

\footnotetext{
195 See http://coptot.manuscriptroom.com/manuscript-workspace/?docID=622008\&fbclid=IwAR3TDe ECwvoRaXyDc0EgFJU6uZ9dFQ5ynkvee0FXCgEV2hK73AQvDM_XL8 [access: 25.04.2020].

196 Perhaps this form appeared under the influence of the manuscript sa $1 \overline{0} 8^{\mathrm{L}}$.

197 Crum, Coptic Dictionary, 78b.

198 Crum, Coptic Dictionary, 483b.

199 Ziegler, Septuaginta, 301.
} 
employs a certain degree of freedom here. ${ }^{200}$ In the text of Isa 48:5, both the verb $\dot{\varepsilon} v \varepsilon \tau \varepsilon i ́ \lambda \alpha \tau o$ and $\dot{\varepsilon} v \varepsilon \tau \varepsilon i ́ \lambda \alpha \nu \tau o$ would be translated into Coptic as $\alpha Y 2 \omega N$. Ziegler's remark does not therefore seem necessary.

\section{Isa 48:6}

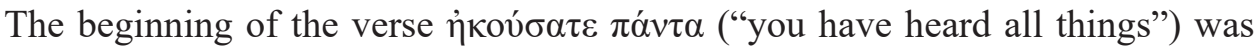

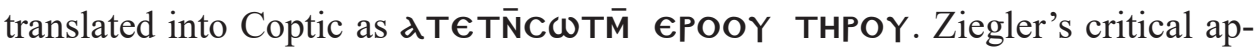
paratus suggests that the Coptic translation reads as if there was pronoun óvió before a Greek $\pi \alpha v^{2} \tau \alpha{ }^{201}$ Given that the Coptic verb "to hear" is used in the struc-

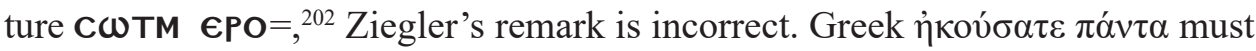
be translated precisely as $\mathbf{A T \epsilon} \overline{\mathrm{N}} \mathrm{C} C \omega \mathrm{T} \overline{\mathrm{M}} \Theta$ POOY THPOY.

\section{Isa 48:21}

The Coptic translation of this verse presents a number of problems:

1) One can notice a different division of words in the sentence right at the beginning. In the elaboration of Septuagint by Ziegler, we read: kai

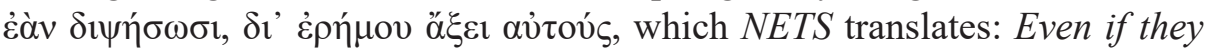
are thirsty, he will lead them through the wilderness. In the Coptic text, we

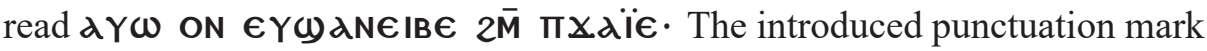
clearly shows that the Coptic translator reads the Greek $\delta i^{\prime} \dot{\varepsilon} \rho \eta \dot{\mu} \mu v$ together

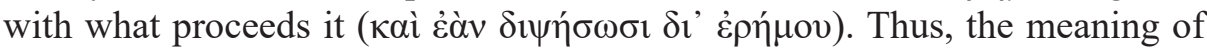
the first part of the verse is changed: Even if they are thirsty in the wilderness.

2) The rest of the Coptic translation poses interpretation difficulties: $€ \mathbf{G N} \boldsymbol{\Phi} \in \overline{\mathbf{M}}$ MOOY NAY. The verb form $€ \mathbf{G N} \mathbf{A} \in \overline{\mathbf{M}}$ is especially complicated. The intial $\boldsymbol{\epsilon}$ - is probably a circumstantial converter, which appears here quite unexpectedly. Perhaps it is a result of a dittography error (the preceding mхd $\ddot{\mathbf{i} \epsilon}$ ends in the same vowel). Alternatively, it could constitute scriptio plena of the $3 \mathrm{sg}$. masculine pronoun -4-, notated here as $\boldsymbol{€} \mathbf{4}-$. A corresponding structure

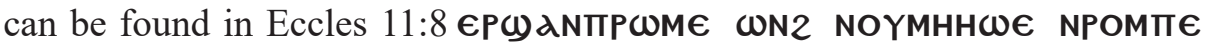
EЧNA€Y4PAN€ N2HTOY THEPOY ("For even if a person will live many years, in them all he will be merry"). The manuscript sa 48 contains the expected form $\mathbf{~} \mathrm{N} \boldsymbol{\mathrm { A }} \overline{\mathrm{M}}$ in Isa 48:21.

The next element is the future auxiliary $\mathbf{N d}$-, followed by the verb $€ \overline{\mathbf{M}}-$. This is probably the prenominal form of the verb $€ \mathbf{I N} €$ ("to bring"), which should have been notated as $\mathbf{\epsilon N}-.^{203}$ In our verse, the consonant $\mathbf{N}$ could have been replaced by $\mathbf{M}$ because of the following noun $\mathbf{M o o \gamma}$. The Coptic translation

200 Cf. F. Blass - A. Debrunner, Grammatica del greco del Nuovo Testamento, 2 ed. (Introduzione allo studio della Bibbia. Suplementi 2; Brescia: Paideia 1997) § 133.

201 Ziegler, Septuaginta, 302.

202 Cf. Layton, Coptic Grammar, § 514.

203 Crum, Coptic Dictionary, 78b. 
EINAEM MOOY NAY should therefore be translated as: he will bring forth water for them. This interpretation is supported by the manuscript sa 48, in which we read: ЧNA $\bar{M}$ MOOY NAY.

A horizontal line appearing above the final consonant is another element hindering an unambiguous reading of the verb form $€ \mathbf{C} \mathbf{N} \boldsymbol{\Phi} \epsilon \bar{M}$ in the manuscript sa 52. It could indicate the beginning of the next word, marking it as the direct object of MMOOY. We would then obtain the notation

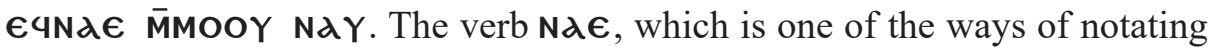
the verb Nd meaning "to have pity, mercy," 204 is known in the Coptic language. However, it is not linked to the direct object, but to the indirect one. Theoretically, if we used the notation $€$ GN $d €\{$ MMOOY\} NAY in the verse, we would obtain the meaning: he shows mercy to them. So the beginning of the verse would begin: Even if they are thirsty in the wilderness, he (= God) shows mercy to them. However, since neither the text of LXX nor the manuscript sa 48 contains any reference to mercy, in our manuscript we adhere to the no-

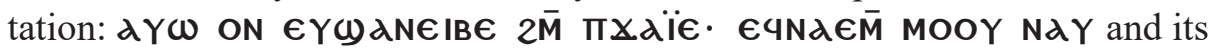
translation: Even if they are thirsty in the wilderness, he will bring forth water for them.

3) We also face difficulties in the next part of the verse. The Coptic text $\mathrm{d} Y \omega$

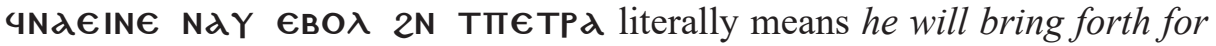
them out of a rock. It lacks the direct object of the verb $€ \mathbf{I N} €$ ("to bring"205). The noun $v \delta \omega \rho$ ("water"), which in the Coptic translation would correspond to the form NoYmooY is such an object in the text of LXX. The literal

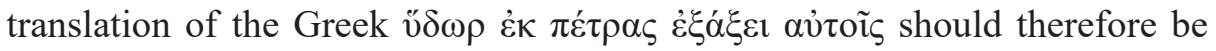

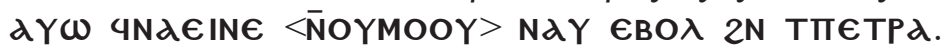

Translated by Grzegorz Knyś

\section{Bibliography}

Amélineau, É., "Fragments de la version thébaine de l’Écriture (Ancien Testament)," Recueil de travaux relatifs à la philologie et à l'archéologie égyptiennes et assyriennes 9 (1887) 101-130.

Atanassova, D., "Zu den sahidischen Pascha-Lektionaren," Orientalia Lovaniensia Analecta 133/2 (2004) 607-620.

Balestri, P.J., Sacrorum Bibliorum Fragmenta Copto-Sahidica Musei Borgiani. III. Novum Testamentum (Roma: Typographia Polyglotta S. C. de Propaganda Fide 1904).

Bąk, T.B., "A Critical Edition and Philological Analysis of the First Chapter of Deutero-Isaiah (Isa 40) on the Basis of the Coptic Manuscript sa 52 (M 568) in Light of Other Coptic Manu-

204 Crum, Coptic Dictionary, 216b.

205 Crum, Coptic Dictionary, 78b. 
scripts Written in the Sahidic Dialect and the Greek Text of the Septuagint," The Biblical Annals 9/1 (2019) 73-100 (=Isa 40).

Bąk, T.B., "A Critical Edition and Philological Analysis of the Second Chapter of Deutero-Isaiah (Isa 41) on the Basis of the Coptic Manuscript sa 52 (M 568) in Light of Other Coptic Manuscripts Written in the Sahidic Dialect and the Greek Text of the Septuagint," The Biblical Annals 10/1 (2020) 63-91 (= Isa 41).

Bąk, T.B., "A Critical Edition and Philological Analysis of the Text of Isa 42:1-44:5 on the Basis of the Coptic Manuscript sa 52 (M 568) and Other Coptic Manuscripts Written in the Sahidic Dialect of Coptic and the Greek Text of the Septuagint," The Biblical Annals 10/2 (2020) 225-260 (=Isa 42:1-44:5).

Bąk, T.B., "A Critical Edition and Philological Analysis of the Text of Isa 44:6-45:25 Based on the Coptic Manuscript sa 52 (M 568), Other Manuscripts Written in the Sahidic Coptic Dialect, and on the Greek Text of the Septuagint," Verbum Vitae 38/2 (2020) 529-563 (=Isa 44:6-45:25).

Bąk, T.B., "Koptyjski przekład Iz 1-39 w manuskrypcie sa 52 (M 568) z VIII w.," The Biblical Annals 5/2 (2015) 289-305.

Bąk, T.B., Il Proto-Isaia in copto-saidico. Edizione critica sulla base di sa 52 (M 568) e di altri testimoni. Estratto della dissertazione per il Dottorato in Studi dell'Oriente Antico (Roma: Pontificio Instituto Biblico, Facoltà Orientalistica 2014).

Bąk, T. B., Proto-Isaiah in the Sahidic Dialect of the Coptic Language. Critical Edition Based on the Coptic Manuscript sa 52 (M 568) and Other Witnesses (Patrologia Orientalis 251; Turnhout: Brepols 2020).

Blass, F. - Debrunner, A., Grammatica del greco del Nuovo Testamento, 2 ed. (Introduzione allo studio della Bibbia. Suplementi 2; Brescia: Paideia 1997).

Ciasca, A., Sacrorum Bibliorum fragmenta copto-sahidica Musei Borgiani iussu et sumptibus S. Congregationis de Propaganda Fide studio P. Augustini Ciasca ordinis Eremitarum S. Agostini edita (Roma: Typis S. Congregationis de Propaganda Fide 1885-1889) I-II.

Crum, W.E., Catalogue of the Coptic Manuscripts in the British Museum (London: British Museum 1905).

Crum, W.E., A Coptic Dictionary (Oxford: Clarendon 1939), Reprint (Eugene, OR: Wipf \& Stock 2005).

Crum, W.E. - Winlock, H.E., The Monastery of Epiphanius at Thebes. I. The Archeological Material by H.E. Winlock. The Literary Material by W.E. Crum (New York: The Metropolitan Museum of Art 1926).

Crum, W.E. - Evelyn White, H.G., The Monastery of Epiphanius at Thebes. II. Coptic Ostraca and Papyri Edited with Translations and Commentaries by W.E. Crum. Greek Ostraca and Papyri Edited with Translations and Commentaries by H.G. Evelyn White (New York: The Metropoli$\tan$ Museum of Art 1926).

Depuydt, L., Catalogue of Coptic Manuscripts in the Pierpont Morgan Library (Corpus van verluchte handschriften 4. Oriental Series 1; Leuven: Peeters 1993).

Feder, F., Biblia Sahidica. Ieremias, Lamentationes (Threni), Epistula Ieremiae et Baruch (Texte und Untersuchungen zur Geschichte der altchristlichen Literatur 147; Berlin - New York: Gruyter 2002).

Fournet, J.L., “Anatomie d'une bibliothèque de l'Antiquité tardive: l'inventaire, la faciès et la provenance de la 'Bibliothèque Bodmer'," Adamantius 21 (2015) 8-40. 
Hebbelynck, A., "Les manuscrits coptes-sahidiques du «Monastère Blanc». Recherches sur les fragments complémentaires de la Collection Borgia. I. Fragments de l'Ancien Testament" Muséon 12 (1911) 1-64.

Hebbelynck, A., "Fragments inédits de la version sahidique d'Isaïe. I. Fragments de la Bibliothèque Nationale de Paris," Muséon 14 (1913) 177-227.

Horner, G.W., The Coptic Version of the New Testament in the Southern Dialect, Otherwise Called Sahidic and Thebaic, with Introduction, Critical Apparatus, and Literal English Translation. III. The Gospel of S. John (Oxford: Clarendon 1911).

Hurtado, L., The Earliest Christian Artifacts. Manuscripts and Christian Origins (Grand Rapids, MI: Eerdmans 2006).

Hyvernat, H., "Étude sur les versions coptes de la Bible. II. - Ce qui nous est parvenu des versions égyptiennes," Revue Biblique 5 (1896) 540-569 (= Étude II).

Kasser, R., Papyrus Bodmer XXIII. Esaïe XLVII,1-LXVI,24 (Cologny - Genève: Bibliotheca Bodmeriana 1965).

Lacau, P., “Textes de l'Ancien Testament en copte sahidique," Recueil de Travaux Relatifs à la Philology et à l'Archéologie Égyptiennes et Assyriennes. Nouvelle Série 7 (1901) 103-124.

Layton, B., A Coptic Grammar. With Chrestomathy and Glossary. Sahidic Dialect. Second Edition, Revised and Expanded. With an Index of Citations (Wiesbaden: Harrassowitz 2004).

Lust, J. - Eynikel, E. - Hauspie, K., Greek-English Lexicon of the Septuagint (Stuttgart: Deutsche Bibelgesellschaft 2003).

Maspero, G., "Fragments de manuscrits coptes-thébains provenant de la bibliothèque du Deir Amba-Shenoudah," Mémoires publiés par les membres de la Mission Archéologique Française au Caire 6 (1892) 1-296.

Myszor, W., Podręczny słownik języka koptyjskiego (Warszawa: Wydawnictwo Akademickie Dia$\log 1996)$.

Nagel, P., "Editionen koptischer Bibeltexte seit Till 1960," Archiv für Papyrusforschung 35 (1990) 43-100.

Nagel, P., "Studien zur Textüberlieferung des sahidischen Alten Testaments," Zeitschrift für Ägyptische Sprache und Altertumskunde 111 (1984) 138-164.

Nongbri, B., God's Library. The Archaeology of the Earliest Christian Manuscripts (New Haven, CT - London: Yale University Press 2018).

Pietersma, A. - Wright, B.G. (eds.), A New English Translation of the Septuagint (New York: Oxford University Press 2007) (= NETS).

Porcher, M.E., "Analyse des manuscrits coptes $131^{1-8}$ de la Bibliothèque Nationale, avec indication des textes bibliques," Revue d'égyptologie 2 (1936) 65-123.

Rahlfs, A., Die alttestamentlichen Lektionen der griechischen Kirche (Mitteilungen des SeptuagintaUnternehmens der Königlichen Gesellschaft der Wissenschaften zu Göttingen 5; Berlin: Weidmann 1915).

Robinson, J.M., "The manuscript's History and Codicology," The Crosby-Schøyen Codex MS 193 in the Schøyen Collection (ed. J.E. Goehring) (Corpus Scriptorum Christianorum Orientalium. Subsidia 85; Louvain: Peeters 1990) XIX-XLVII.

Schleifer, J., Sahidische Bibel-Fragmente aus dem British Museum zu London (Sitzungsberichte der Kaiserlichen Akademie der Wissenschaften in Wien. Philosophisch-historische Klasse 162/6; Wien: Hölder 1909). 
Schmitz, F.J. - Mink, G., Liste der Koptischen Handschriften des Neuen Testaments. I. Die sahidischen Handschriften der Evangelien (Arbeiten zur Neutestamentlichen Textforschung 15; Berlin - New York: De Gruyter 1991) 2/2.

Schüssler, K., Das sahidische Alte und Neue Testament: sa 21-48 (Biblia Coptica 1/2; Wiesbaden: Harrassowitz 1996).

Schüssler, K., Das sahidische Alte und Neue Testament: sa 93-120 (Biblia Coptica 1/4; Wiesbaden: Harrassowitz 2000).

Schüssler, K., Das sahidische Alte und Neue Testament: sa 185-260 (Biblia Coptica 2/2; Wiesbaden: Harrassowitz 2015).

Suciu, A., "The Sahidic Tripartite Isaiah: Origins and Transmission within the Coptic Manuscript Culture," Archiv für Papyrusforschung 66/2 (2020) 377-406.

Takla, H.N., "The Surviving Remains of the Book of Jeremiah from Saint Shenouda's Monastery," Coptica 9 (2010) 83-89.

Till, W.C., "Papyrussammlung der Nationalbibliothek in Wien. Katalog der koptischen Bibelbruchstücke. Die Pergamente," Zeitschrift für die neutestamentliche Wissenschaft 39 (1940) 1-57.

Till, W.C., "Die Coptica der Wiener Papyrussammlung," Zeitschrift der Deutschen Morgenländischen Gesellschaft 95 (1941) 165-218.

Till, W.C., "La séparation des mots en copte," Bulletin de l'Institut Français d'Archéologie Orientale 60 (1960) 151-170.

Vaschalde, A., "Ce qui a été publié des versions coptes de la Bible," Revue Biblique 16 (1919) 220-243.

Vaschalde, A., "Ce qui a été publié des versions coptes de la Bible," Revue Biblique 29 (1920) 241-258.

Wessely, C., Griechische und koptische Texte theologischen Inhalts (Studien zur Palaeographie und Papyruskunde 15; Leipzig: Haessel 1914) IV.

Winstedt, E.O., "Some Unpublished Sahidic Fragments of the Old Testament," The Journal of Theological Studies 10 (1909) 233-254.

Ziegler, J. (ed.), Septuaginta. Vetus Testamentum Graecum. Auctoritate Societatis Litterarum Gottingensis editum. XIV. Isaias (Göttingen: Vandenhoeck \& Ruprecht 1939).

Zoega, G., Catalogus codicum copticorum manu scriptorum qui in museo Borgiano velitris adservantur (Roma: Typis Sacrae Congregationis de Propaganda Fide 1810). 
